\title{
Discovery of shale gas in organic-rich Jurassic successions, Adventdalen, Central Spitsbergen, Norway
}

\author{
Sverre Ekrene Ohm ${ }^{1,2}$, Leif Larsen ${ }^{3}$, Snorre Olaussen' ${ }^{1}$ Kim Senger ${ }^{1}$, Thomas Birchall ${ }^{1,4}$, \\ Thomas Demchuk ${ }^{5}$, Andrew Hodson', Ingar Johansen ${ }^{6}$, Geir Ove Titlestad7, \\ Dag A. Karlsen ${ }^{4}$ \& Alvar Braathen ${ }^{1,4}$
}

\author{
${ }^{1}$ Department of Arctic Geology, The University Centre in Svalbard, PO box 156, 9171 Longyearbyen, Norway. \\ ${ }^{2}$ Department of Energy Resources, University of Stavanger, P.O. Box 8600 Forus, 4036 Stavanger Norway. \\ ${ }^{3}$ KAPPA Engineering, Myklabergstien 15, N-4052 Røyneberg, Norway. \\ ${ }^{4}$ Department of Geosciences, University of Oslo, PO Box 1047 Blindern, 0316 Oslo, Norway. \\ ${ }^{5}$ RPS Group Inc, Chasewood Technology Park, 20405 Tomball Parkway, Building Two, Suite 200, Houston, Texas 77070-2618, USA. \\ ${ }^{6}$ Institute for Energy Technology, Instituttveien 18, 2007 Kjeller, Norway. \\ ${ }^{7}$ Gotic AS, P.O. Box 8034 Forus, 4068 Stavanger, Norway.
}

\section{E-mail corresponding author (Sverre Ekrene Ohm): sverre.e.ohm@uis.no}

Thermogenic dry gas flowed from Jurassic sections in the DH5R research well drilled onshore in Adventdalen, central Spitsbergen, Arctic Norway. The DH5R gas originates from the organic-rich units of the mudstone-dominated Middle Jurassic to Lower Cretaceous Agardhfjellet Formation, which is the onshore equivalent to the Fuglen Formation and the prolific oil and gas generating Hekkingen Formation in the southern Barents Shelf. Low-permeable, low-porosity sandstones from the Upper Triassic De Geerdalen Formation of the neighbouring DH4 well were oil-stained and gas was also collected from this interval. Gas from the two stratigraphic intervals have different compositions; the gas from the Agardhfjellet Formation is drier and isotopically heavier than the gas from the Upper Triassic succession. Both gases originated from source rocks of maturity near the end of the oil window $(1.1<$ Ro $<1.4 \%$ Ro). Maceral analyses of the Agardhfjellet Formation indicate that the more silty parts contain a high percentage of vitrinite-rich type III kerogen, whereas the clay-dominated parts are rich in liptinitic type II kerogen. The Agardhfjellet Formation has therefore the potential to generate both oil and gas. Several simulations based on pressure data and flow rates from the DH5R well were run to evaluate if the gas accumulation in the Agardhfjellet Formation is producible, i.e., can it be commercial shale gas. The models demonstrate how changes in the drainage area size and form, well types (vertical versus horizontal), number and length of induced fractures and thickness of the Agardhfjellet Formation affect gas production rates and producible volumes. Despite uncertainties in the input data, simulations indicate that the shale gas accumulation characterised in Adventdalen is producible. This gas can have major environmental benefits as an alternative for local power generation compared to coal.

Keywords: Thermogenic gas, Svalbard, shale gas, unconventional, permafrost, maturation, pressure, stable isotopes.

Received 31. May 2019 / Accepted 5. November 2019 / Published online 9. January 2020

\section{Introduction}

The rising global demand for energy puts pressure on both existing fossil fuel resources and alternative energy carriers to supply energy at an acceptable economic, social and environmental cost. Currently, the energy system in Longyearbyen is relying on locally produced coal and imported diesel. To lower the $\mathrm{CO}_{2}$ emission, gas can be a temporary solution to characterise different energy carriers in terms of their costs, and is of high societal relevance considering the uncertain energy future in Longyearbyen (Tennbakk et al., 2018). In this context, we investigate a gas accumulation in Adventdalen discovered during a recent $\mathrm{CO}_{2}$ sequestering feasibility study.

Ohm, S.E., Larsen, L., Olaussen, S., Senger, K., Birchall, T., Demchuk, T., Hodson, A., Johansen, I., Titlestad, G.O., Karlsen, D.A. \& Braathen, A. 2019: Discovery of shale gas in organic-rich Jurassic successions, Adventdalen, Central Spitsbergen, Norway. Norwegian Journal of Geology 99 , 343-370. https://dx.doi.org/10.17850/njg007. 
Diamond drilling was used for eight boreholes near Longyearbyen, DH1 to DH8, that were fully cored for testing $\mathrm{CO}_{2}$ storage feasibility (Fig. 1; Braathen et al., 2012). The deepest well, DH4, was drilled to a total depth (TD) of $972 \mathrm{~m}$. The DH1 to DH8 boreholes were drilled at two separate drill sites. DH1 and DH2 were drilled northwest of the settlement near Longyearbyen airport, while the remaining boreholes were drilled in Adventdalen, $4 \mathrm{~km}$ southeast of Longyearbyen (Fig. 1).

Well and 2D seismic data were integrated with laboratory and geological field studies to delineate a potential unit for $\mathrm{CO}_{2}$ captured in the local coal-fueled power plant (Braathen et al., 2012). The sandstone reservoir (i.e., aquifers) comprises the Upper Triassic to Middle Jurassic Kapp Toscana Group, and is characterised by low matrix permeability and low to moderate porosity, reflecting paleo deep burial (Mørk, 2013). Water injection tests within these units show increased effective permeability, which is believed to be a result of natural fractures in the sandstones (Ogata et al., 2014; Mulrooney et al., 2019). The overlying organic-rich shales of the Middle Jurassic to Lower Cretaceous units of the Agardhfjellet and Rurikfjellet formations are potential cap rocks for buoyant fluids (Senger et al., 2016; Koevoets et al., 2019). The mudstone-dominated Agardhfjellet Formation is highly fractured. Both the reservoir and at least part of the cap rock are severely under pressured, by up to 50 bar below hydrostatic pressure (Birchall et al., 2018). The uppermost $250 \mathrm{~m}$ of the drilled succession is slightly over pressured by artesian water flow and is capped by approximately $120 \mathrm{~m}$-thick permafrost at drill site 2 (Braathen et al., 2012; Betlem et al., 2019).

Open-system pingos in Adventdalen reveal the presence of a biogenic, methane-rich sub-permafrost groundwater with a $\delta^{13} \mathrm{C}$-methane signature of between $-71 \%$ and $-48 \%$. The water shows dissolved methane concentrations (up to the solubility limit of $41 \mathrm{mg} / \mathrm{L}$ at $0^{\circ} \mathrm{C}$ ) associated with saline porewater. This water is derived from former marine sediments that fill the valley bottom up to the marine limit at c. $70 \mathrm{~m}$. Although some of the $\delta^{13} \mathrm{C}$-methane values heavier than $-55 \%$ may indicate the possible presence of thermogenic methane, partial oxidation of biogenic methane is a more likely explanation (Hodson et al., In review).

Gas seeps in both shallow and deep units were encountered in all wells drilled, while oil-stained sandstones were found in the deeper Triassic successions. Geochemical analysis of gas and oil-stained sandstone of the Upper Triassic De Geerdalen Formation at $870 \mathrm{~m}$ to TD in well DH4 suggests that petroleum was originally sourced from the organic-rich marine mudstone (OMM)

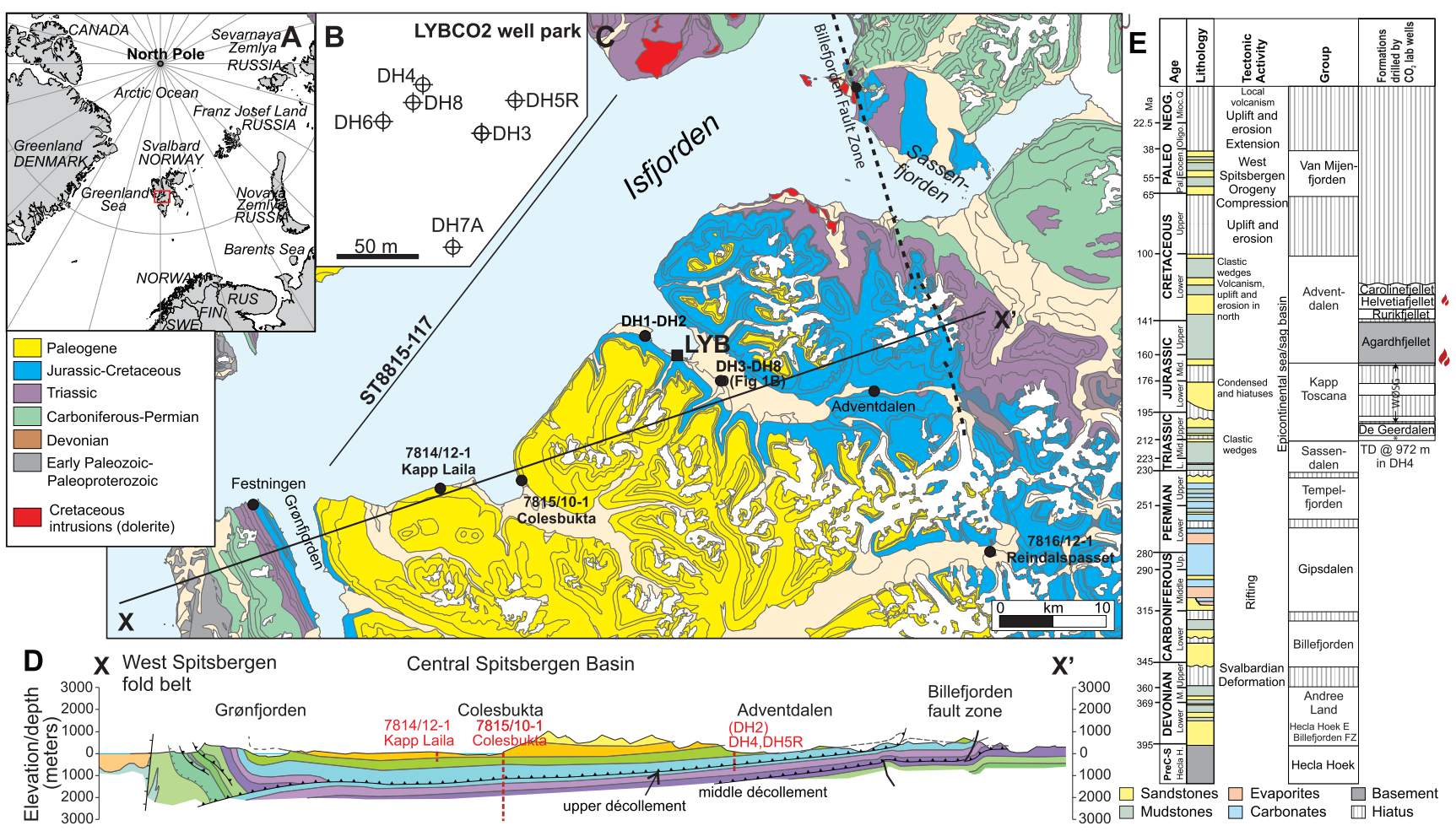

Figure 1. Geological overview of the study area, modified from Koevoets et al. (2018). (A) Location map of the Svalbard archipelago, with the study area highlighted by the red rectangle. (B) Zoom-in of the UNIS CO2 lab well park in Adventdalen, where six wells were drilled in close proximity. (C) Geological map of the study area, including the location of some of the conventional hydrocarbon exploration boreholes, based on Dallmann et al. (2001). (D) Regional cross-section across the Central Spitsbergen Basin. For location, see Fig. 1B. (E) Regional stratigraphic column highlighting the stratigraphic position of the Agardhfjellet Formation, modified from Nøttvedt et al. (1993b). Digital geological map, courtesy of the Norwegian Polar Institute. 
of the Middle Triassic Botneheia Formation (Abay et al., 2017). After a water injection test in well DH7A, leak offtest (LOT) in DH5R, and cross-well flow test between boreholes DH7A and DH5R, gas was encountered in both wells. All tests were executed in open hole, which includes 25 to $30 \mathrm{~m}$ of organic-rich mudstone of the basal part of the Agardhfjellet Formation, $25 \mathrm{~m}$ of the sandstone and shales of the Wilhelmøya Subgroup, and at the base until total depth (TD), 3 to $4 \mathrm{~m}$ of heterolithic shale and sandstone of the top part of the De Geerdalen Formation.

The purpose of the cross well-flow test between wells DH5R and DH7A, which were drilled $94 \mathrm{~m}$ from each other, was to investigate the lateral continuity of fluid flow in the Wilhelmøya Subgroup. The test showed only minor or no communication between the wells (see Mulrooney et al., 2019 for details). After a water injection test, which proved no lateral connection in the Wilhelmøya Subgroup, water was sucked into the formation and replaced with methane gas in the wellbore resulting in a well head pressure of 24 to 25 bar. The gas was repeatedly bled off from well DH5R to 1 bar at the surface. The pressure rebuilt after roughly 24 hours. During a water injection test in DH5R, the surface pressure dropped over a one month period from 24-25 to 6.7 bar. Gas-saturated shales were surprisingly encountered in Adventsdalen after leak-off testing of the potential top seal of the shale-dominated Agardhfjellet Formation.

In this study, we use geochemical analyses, wireline logs, production test data, and maceral analyses to thoroughly document the gas discovery in Adventdalen. Furthermore, we present production scenarios with a range of possible production strategies to quantify the production potential of the discovery, and discuss its potential for local energy use.

\section{Geological setting}

The Svalbard archipelago is situated in the northwestern corner of the Eurasian continent. The Precambrian to Cretaceous strata on Svalbard represent the exposed part of the subsurface of the Barents Shelf (Nøttvedt et al., 1993a; Worsley, 2008). The Svalbard platform is bordered on its western and northern flanks by the Cenozoic opening of the Norwegian-Greenland Sea and the Eurasia Basin, respectively (Faleide et al., 2015). The Upper Palaeozoic and Mesozoic basin fill in Svalbard, and the southwestern part of the Barents Shelf, is bounded by two major global plate-tectonic events; the Caledonian Orogeny, and the Cenozoic break-up of the NE Atlantic (Norwegian-Greenland Sea) and Arctic Eurasia Basin (Faleide et al., 2015). In Svalbard, the last event was part of the Eurekan Orogeny (Piepjohn et al., 2016).
The Carboniferous and Permian succession in Svalbard consists of mixed siliciclastic, carbonate, evaporite and silica deposited in rift basins (Steel \& Worsley, 1984). The Mesozoic is dominated by mixed sandstones and shales deposited in epicontinental or sag basins. West Spitsbergen was a sediment sink, sourced from the west in the Early and Middle Triassic (Mørk et al., 1982), and from the east in the Late Triassic. The Triassic basin fill in the Barents Sea was mostly sourced from the east and southeast as a consequence of denudation of the Uralian mountain chain and Fennoscandia (Glørstad-Clark et al., 2010; Klausen et al., 2017). Flooding with high organic production in the Middle Triassic resulted in the deposition of the Botneheia Formation, one of the major source rocks in the southwestern Barents Sea (Mørk et al., 1999; Krajewski et al., 2007; Krajewski, 2008; Ohm et al., 2008; Abay et al., 2017). In the Late Triassic to Middle Jurassic the subsidence rate decreased (Ryseth, 2014) leading to more complex source to sink trends (Klausen et al., 2017, 2018; Rismyhr et al., 2019). While the western boundary of the Barents Shelf was part of the North Atlantic Middle Jurassic to Lower Cretaceous rift system, Svalbard and nearby platform areas continued to subside as sag basins with a weak compressional influence from the east (Grogan et al., 1999).

The mudstone-dominated Bathonian to Ryazanian, Agardhfjellet Formation, containing organic-rich units, is approximately $220 \mathrm{~m}$ thick in central western Spitsbergen (Dypvik, 1984; Koevoets et al., 2019). The organic-rich mudstones within the Agardhfjellet Formation, often characterised as paper shale in outcrops, are the onshore equivalent of the Fuglen Formation and the prolific source rock of the Hekkingen Formation on the Barents Shelf (Worsley, 2008). Nagy et al. (2009) suggested that the Agardhfjellet Formation was deposited in a stratified water column, with high organic production under changing anoxic, dysoxic, and oxic seafloor conditions. Recent studies suggest periodic deposition under very shallow water into the fair weather wave base (Koevoets et al., 2019). During the Early Cretaceous, uplift continued in the north and northwest with clastic wedges building out from the west, northwest and northeast as well from local point-sourced internal highs and rift shoulders (Midtkandal \& Nystuen, 2009; Marín et al., 2016; Grundvåg et al., 2017, 2019). The provenance area gradually shifted to the north/ northwest, and is related to rift and drift to the opening of the Amerasian Basin and associated High Arctic Large Igneous Province (HALIP) in the north (Grantz et al., 2011; Senger et al., 2014). Upper Cretaceous sedimentary rocks have not been observed in Svalbard (Smelror \& Larssen, 2016), probably as a result of uplift of the northern margin of the Barents Shelf (Maher, 2001).

Contraction by transpressional tectonics in the Paleogene created the West Spitsbergen Fold-and-Thrust Belt (WSFTB) and the subsequent development of a foreland basin: the Central Tertiary Basin (CTB; Bergh 
et al., 1997; Braathen et al., 1999; Leever et al., 2011). Seafloor spreading was established in the earliest Eocene. The Paleogene basin fill in our study area, i.e., near the axis of the CTB in Spitsbergen, experienced subsidence throughout the Paleogene. Uplift, renewed volcanism and glaciation characterise the Neogene and is further discussed below.

\section{Burial, temperature history effecting the maturation of the Agardhfjellet Formation in central Spitsbergen}

The Upper Cretaceous and Circum-Arctic basaltic magmatic activity during the Early Cretaceous resulted in the emplacement of numerous sills and dykes in the study area (Senger et al., 2013, 2014). The magmatism might have locally raised the temperature gradient (Brekke et al., 2014; Polteau et al., 2016). However, the Agardhfjellet Formation in our study area appears only locally affected and is thought to have been immature throughout the Mesozoic. The Cenozoic burial history and subsequent unroofing likely had the greatest influence on the maturation and pore pressure of the Agardhfjellet Formation. The Eurekan transpressional tectonism with formation of the WSFTB and the associated foreland basin, the CTB, in the Paleogene, contributed to continuous burial of the Mesozoic succession in Adventdalen. Later transtension and breakup in the Eocene (Steel et al., 1985; Bergh et al., 1997; Helland-Hansen, 2010; Leever et al., 2011) with associated volcanism probably raised the paleo-temperature gradient significantly. Based on vitrinite reflectance analysis, Marshall et al. (2015) suggested that the base-Paleocene experienced maximum burial temperatures of $120^{\circ} \mathrm{C}$ in the central part of the CTB indicating a thermal gradient of approximately $50^{\circ} \mathrm{C} / \mathrm{km}$. Even today, the gradient remains high with well $\mathrm{DH} 4$ exhibiting a temperature of nearly $40^{\circ} \mathrm{C}$ at $970 \mathrm{~m}$ (Braathen et al., 2012). The Cenozoic burial history of the CTB is complex with partially contradictory data. More recent burial history studies suggest that maximum burial occurred in the Middle Eocene (Marshall et al., 2015; Dörr et al., 2019). The uplift during the last few million years, with associated glaciation and erosion (Dimakis et al., 1998) is probably the single most important geological event for Paleogene-Neogene migration and preservation of hydrocarbon accumulations for large parts of the Barents Sea (Cavanagh et al., 2006; Ohm et al., 2008). Abay et al. (2017) drew a similar conclusion from residual bitumen in Svalbard.

Based on well data, 2D seismic lines, outcrop data, and geological maps of the study area, a structural contour map of the base Agardhfjellet Formation for central Spitsbergen was compiled (Fig. 2A). This map has several uncertainties in the subsurface areas particularly in the blue coloured areas due to limited well data and the lack of seismic data in the folded and thrusted area related to thin-skinned tectonics of the WSFTB (Fig. 1D) (Bergh et al., 1997). Generally, however, the map gives a correct picture of the westward-dipping surface (Fig. 2B,C). The map shows that to the west of our study area, the base of the Agardhfjellet Formation is buried to at least 300-350 $m$ deeper than in well DH5R.

\section{Methods and data}

The Agardhfjellet Formation was characterised using a wireline log suite of gamma-ray, velocity and resistivity data and sedimentological, biostratigraphical and geochemical studies (Koevoets et al., 2016, 2019; Abay et al., 2017). Previously unpublished maceral compositions from four DH5R samples (Table 1) and vitrinite reflectance data (Table 2) from well DH4 were supplemented to these studies.

Gas samples were collected in gas bags at well head (Fig. 3) and analysed at IFE (Institute for Energy Technology) for molecular composition and carbon isotopes of individual gas components. Gas compositions (methane $(\mathrm{C} 1)$, ethane $(\mathrm{C} 2)$, propane $(\mathrm{C} 3)$, butanes $(\mathrm{C} 4)$ to pentanes (C5) and $\mathrm{CO}_{2}$ ) were measured using gas chromatography (GC; Agilent 7890 RGA) and stable isotopes $\left(\delta^{13} \mathrm{C}\right)$ were measured using gas chromatography isotope ratio mass spectrometry (Nu Horizon GC IRMS) as described by Huq et al. (2017).

\section{Pressures and leak-off and gas test}

Pressure was monitored in wellbores DH4 and DH5R while they were shut-in with downhole pressure sensors hanging on the wireline. In DH4, well pressures of 31 and 29.6 bars were encountered in the upper and lower Triassic reservoirs, respectively (Fig. 3). These pressures equate to under pressures in excess of 50 bar below hydrostatic (Braathen et al., 2012; Larsen, 2013a, b; Birchall et al., 2018). The measured pressures represent a maximum possible reservoir pressure, but it is possible that pressures are even lower and have been elevated by invasion of drilling fluids. When gas entered the DH5R wellbore, it reached equilibrium with the gas-bearing interval of the Agardhfjellet Formation at 28.9 bar (Larsen, 2012), highlighting that similar under pressure extends into the cap rock. Water with potassium chloride was used as a drilling fluid and was lost from the wellbore during drilling of several wells. The drilling fluid was likely lost into the Wilhelmøya Subgroup, and this is further evidence of under pressure. The Cretaceous Helvetiafjellet Formation, overlying the shales of the Janusfjellet Subgroup (Agardhfjellet and Rurikfjellet formations), is slightly overpressured (Fig. 3). Although no quantitative measurements were taken 

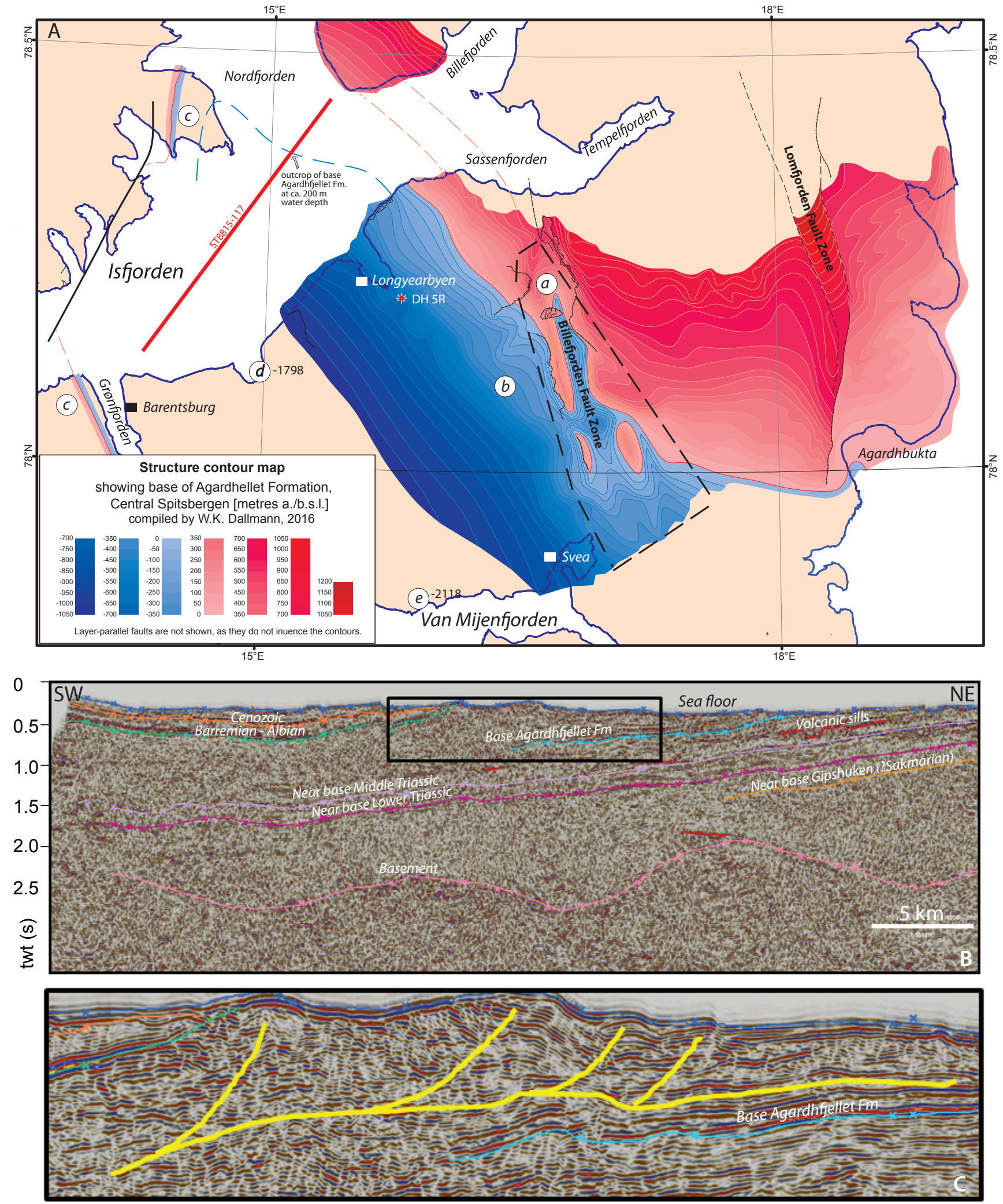

Figure 2. Regional implications of the shale gas discovery in Adventdalen in central-western Spitsbergen. (A) Structural contour map of the Agardhfjellet formation. The letters in the figure refer to the following comments: (a) Folding in this area is constructed by extrapolating formation thicknesses to depth. However, these folds are probably developed above a detachment in the Agardhfjellet Formation and thus, do not affect the base of the formation. (b) Contour lines West of the Billefjorden Fault Zone refer to the upper detached thrust sheet only. (c) Uncertain thickness due to fold belt formation. ( $d \& e$ ) The value from well 7814/12-1 and 7715/3-1 is probably due to subsurface thrust faulting. (B) 2D Seismic line ST 8815-117 illustrates a regional trend of the Agardhfjellet Formation (Interpretation provided by Tormod Henningsen) (C) Inset from ST 8815-117 highlighting the décollement and associated thrust faults. 
Table 1. Mineral and maceral composition of the 4 analysed samples from well DH5R. Only the volumetrically major mineral assemblages, clay and quartz, are listed. The high percentage of solid bitumen noted at $624.7 \mathrm{~m}$ depth coincides with a low quartz content. This makes the shale less brittle and it may consequently trap generated petroleum.

\begin{tabular}{lccccccc}
\hline \multicolumn{1}{c}{ Well } & Depth $(\mathbf{m})$ & \% Vitrinite & \% Inertinite & \% solid Bitumen & \% Liptinite & \% Clay & \% Quartz \\
\hline DH5R & 536.5 & 11.0 & 2.5 & 14.3 & 74.7 & 59.4 & 28.5 \\
DH5R & 555.4 & 78.9 & 5.6 & 10.5 & 10.5 & 27.5 & 62.5 \\
DH5R & 606.7 & 4.4 & 3.0 & 27.8 & 67.8 & 39.9 & 47.1 \\
DH5R & 624.7 & 3.8 & 12.5 & 86.8 & 9.4 & 55.3 & 28.5 \\
\hline
\end{tabular}

Table 2. Vitrinite reflectance versus depth for well DH4.

\begin{tabular}{|c|c|c|}
\hline Well & Depth (m) & Ro (\%) \\
\hline DH4 & 109.5 & 1.18 \\
\hline DH4 & 115.2 & 0.84 \\
\hline DH4 & 127.0 & 1.09 \\
\hline DH4 & 143.0 & 0.90 \\
\hline DH4 & 143.1 & 0.79 \\
\hline DH4 & 143.7 & 0.73 \\
\hline DH4 & 161.2 & 1.06 \\
\hline DH4 & 189.7 & 0.89 \\
\hline DH4 & 434.5 & 0.63 \\
\hline DH4 & 490.3 & 1.23 \\
\hline DH4 & 572.5 & 1.44 \\
\hline DH4 & 689.0 & 1.55 \\
\hline DH4 & 758.0 & 1.00 \\
\hline DH4 & 768.3 & 2.08 \\
\hline DH4 & 789.5 & 1.50 \\
\hline DH4 & 804.5 & 1.64 \\
\hline DH4 & 869.7 & 1.44 \\
\hline DH4 & 925.0 & 1.82 \\
\hline
\end{tabular}

in this interval, water flowing to the surface indicates a few bars of overpressure with artesian origin.

A leak-off test was performed in well DH5R at 645-648 $\mathrm{m}$. When drilling continued, the drilling fluid was lost, most likely into fractures formed during the leak-off test. The interval $645-648 \mathrm{~m}$ was therefore cemented and further drilling to $701 \mathrm{~m}$ (TD) proceeded without further loss of drilling fluid. As gas replaced water in the open hole section $(648-701 \mathrm{~m})$ it was decided to test the well for gas production (Fig. 4). The lowermost $30 \mathrm{~m}$ of the open hole section consists of interbedded sandstone and shale from the water-saturated reservoir of the Wilhelmøya Subgroup. The uppermost $25 \mathrm{~m}$ comprises organic-rich sandy mudstone of the Agardhfjellet Formation (Figs. 4 \& 5). A "thermal mass flow" method was used for the gas test. The thermal flow sensor should have been connected to a laptop with dedicated software to record flow parameters, but this set-up was not successful. Data was instead recorded manually from the display without any problems. Although the flow sensor was designed to measure rates up to $40 \mathrm{Sm}^{3} / \mathrm{hr}$ there were no problems measuring the actual rates that turned out to be higher but less than $100 \mathrm{Sm}^{3} / \mathrm{hr}$.

\section{Results}

The leak-off test performed in the organic-rich 645$648 \mathrm{~m}$ interval (Figs. 3A \& 4) of the Agardhfjellet Formation, is suggested to have led to the formation of new fractures or opened pre-existing fractures. This may have resulted in release and flow of gas trapped in the source rock, analogous to the successful unconventional shale gas exploration in the US (Energy Information Administration, 2018a). A water injection test of the neighbouring well, DH7A, implies that there was one fluid phase in the Wilhelmøya Subgroup. Gas was encountered in well DH7A before water injection. This gas was, however, not tested as this well was drilled to the same depth as DH5R where gas was tested in the same depth interval (Table 3).

Metre-scale faults and igneous intrusions may, however, contribute to compartmentalisation of the very lowpermeability reservoir (Mulrooney et al., 2019). Generally, there is a drop in the resistivity logs below the high-resistivity Lardyfjellet Member including where the leak-off test was performed (Fig. 5). This indicates that the open hole tested interval 645-701 m does not represent a conventional high-saturation petroleum reservoir, and consequently that the tested gas originates from the shale fractured by the leak-off test. High resistivity within the Lardyfjellet Member coincides with elevated gamma-ray and reduced velocity. This is attributed to the presence of highly organic-rich shales as confirmed by total organic carbon (TOC) analysis on the drillcores (Koevoets et al. 2019).

\section{Geochemical analyses of gas}

Eighty core samples were collected from wells DH6 and DH7A. Gases expelled from these due to pressure decrease were collected and analysed for composition and carbon isotope values (Huq et al., 2017). The results, illustrated in Fig. 6 and listed in Table 4, show a 


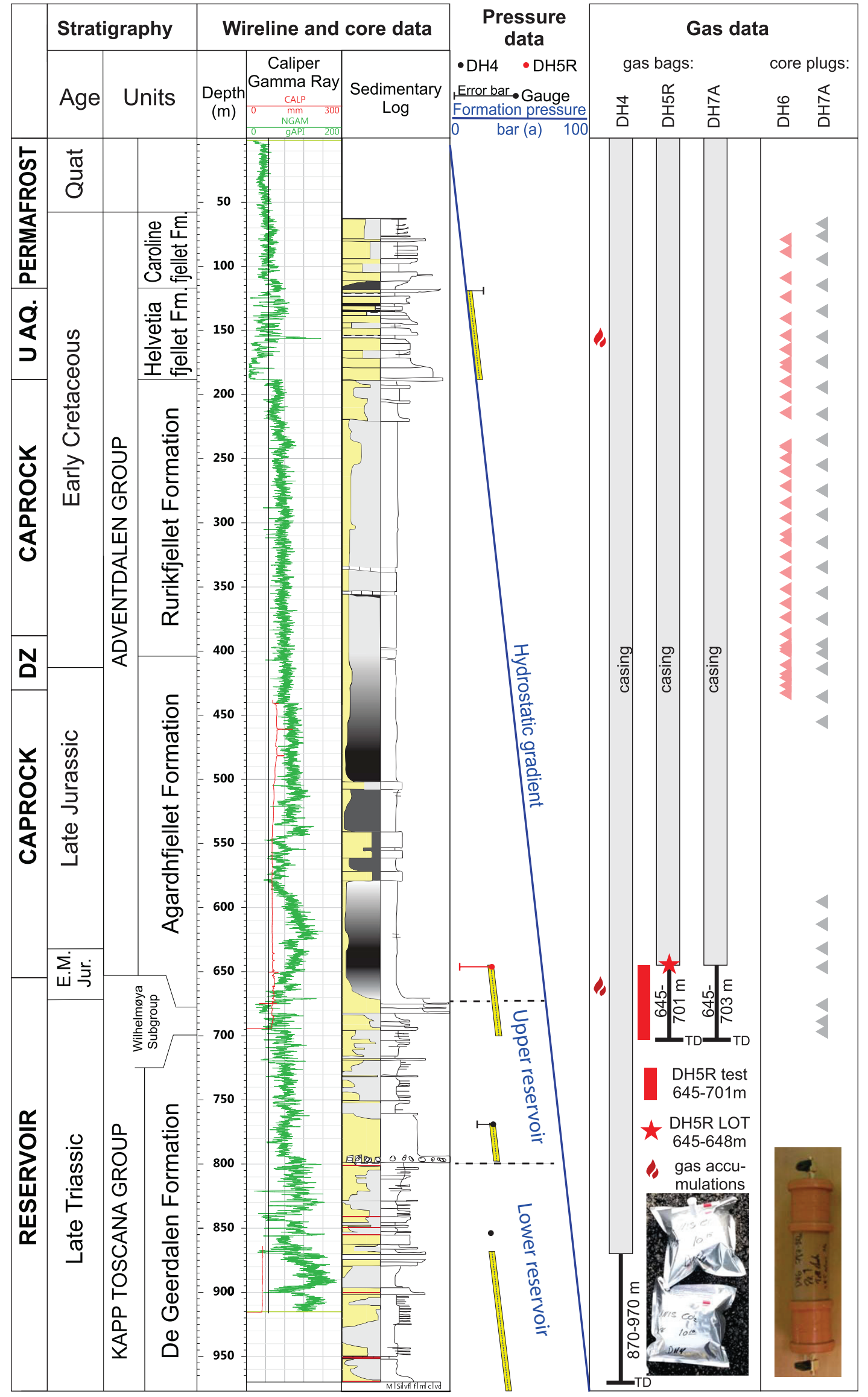

Figure 3. (A) Stratigraphy and overview of gas data at the UNIS $\mathrm{CO}_{2}$ lab well park in Adventdalen. A detailed log of the interval from 430 to $710 \mathrm{~m}$ is provided in Fig. 5. The inset photos show the gas bags sampled from gas production from the DH4 well and custom built containers for sampling drillcore gas. Both photos by IFE (Huq et al., 2017). U. Aq - Upper Aquifer, DZ - Décollement zone. 


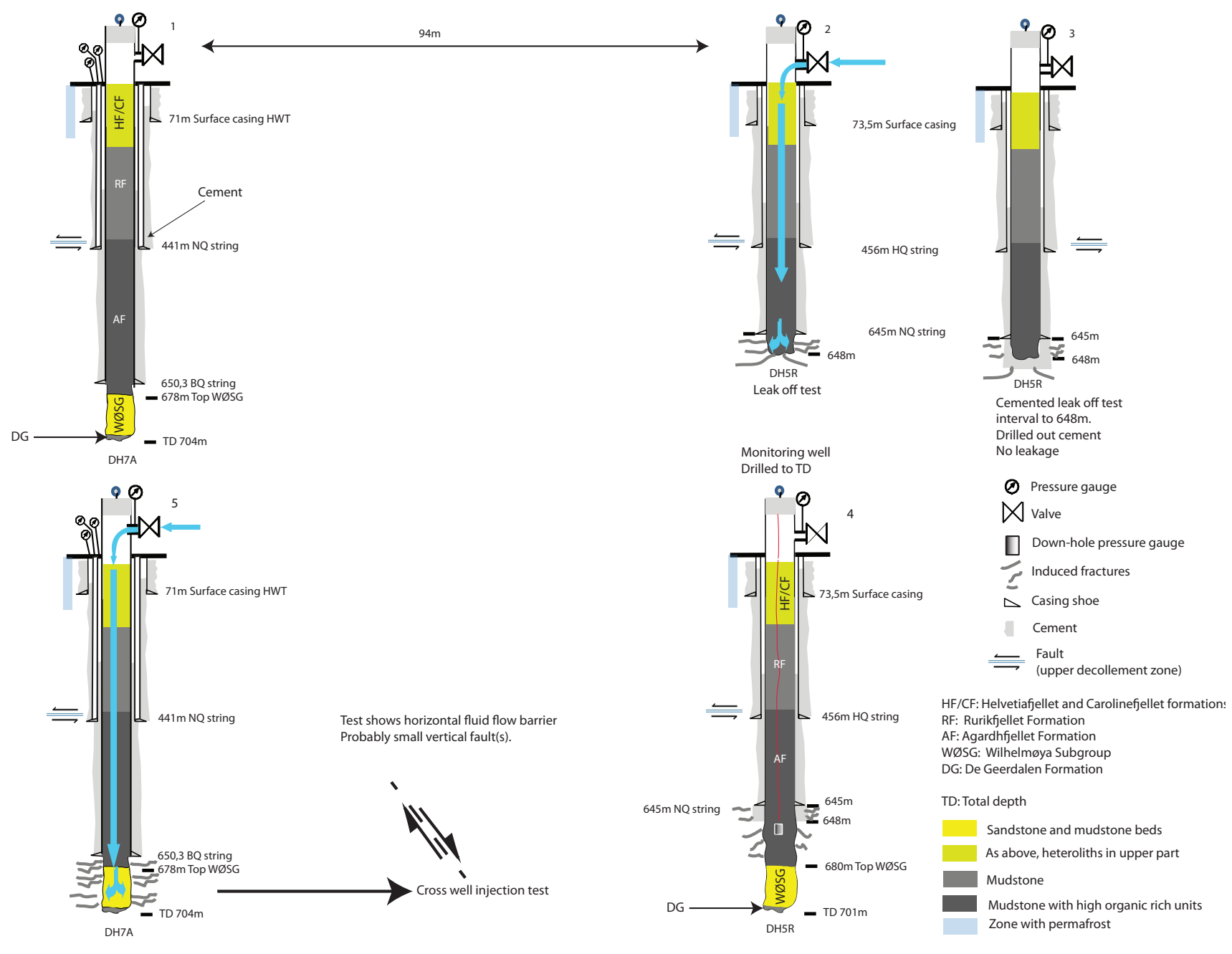

B

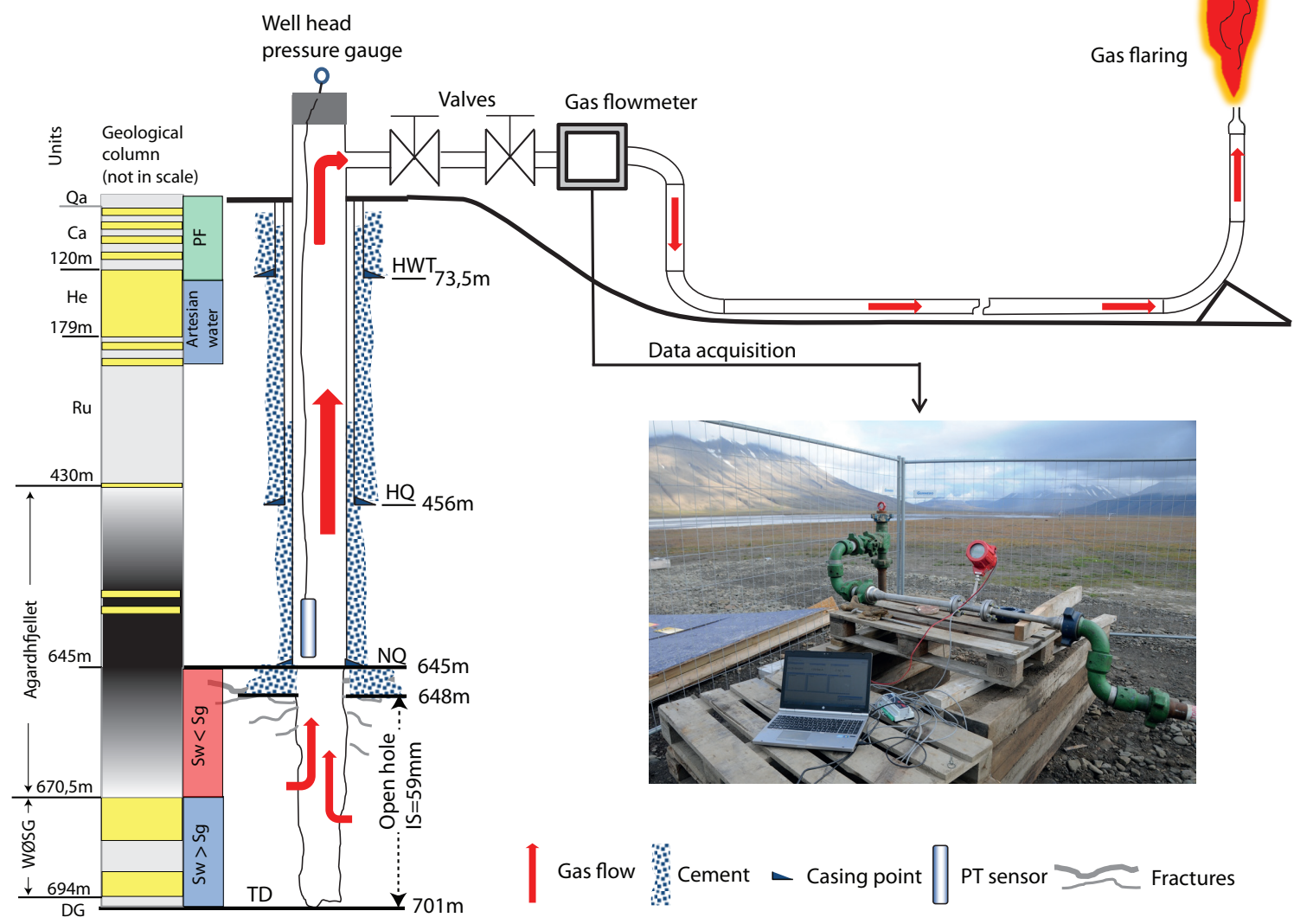


Figure 4. Well design for leak-off, cross-well water injection and open hole gas tests. (A) Well design and flow diagram of DH5R and DH7A. (1) DH7A drilled to planned total depth (TD). (2) The drilling rig moved to DH5R for Leak-off test (LOT). (3) The well was drilled to $645 \mathrm{~m}$, cemented and tested for leakage. Subsequently, the cement was drilled out, and the well extended to $648 \mathrm{~m}$, i.e., $3 \mathrm{~m}$ open hole for LOT. (4) After LOT the well was drilled to planned TD at $701 \mathrm{~m}$ and a pressure gauge was placed in the well. (5) Testing equipment was moved to DH7A for cross well flow testing. In the meantime DH7A was filled with gas with a well head pressure of 25 bar. Before cross-well water injection, the test gas was flared off. The test recorded either no or only minor communication between DH5R and DH7A suggesting the presence of a vertical barrier for fluid flow between them. Gas also started to fill up well DH5R and reached 24 bar as well-head pressure leading to planning of an open hole gas test. (B) Technical design and flow diagram of the open hole test in DH5R, Sw - Water saturation, Sg - Gas saturation, Yellow - Sandstone, Grey - Mudstone, Dark grey - Organic-rich mudstone, PF - Permafrost, Q - Quaternary, $\mathrm{Ca}$ - Carolinefjellet Formation, He - Helvetiafjellet Formation, Ru Rurikfjellet Formation, WØSG - Wilhelmøya Subgroup, DG - De Geerdalen Formation. Rod casing; HWT - 101.6 mm, but no core; HQ $-78 \mathrm{~mm} ; \mathrm{NQ}-60 \mathrm{~mm}$.

gradual change in the methane carbon isotopes $\left(\delta^{13} \mathrm{C}\right)$ from light values at shallow depth (Group A) to heavy values at the base (Group E). This reflects a change from biogenic to thermogenic gas. The general increase in the concentration of ethane $\left(\mathrm{C}_{2}\right)$ to butane $\left(\mathrm{C}_{4}\right)$ supports this. The increased relative concentration of $\mathrm{C}_{6+}$ in the sandstone underlying the Agardhfjellet Formation shows that this interval contains petroleum in the liquid range (Fig. 6). As previously discussed, however, low resistivity in this interval rules out that the sand contains highsaturation producible oil and, therefore, merely indicates that it contains residual petroleum.

Additional gas samples from the $\mathrm{DH}$ wells are plotted in Fig. 7. The figure supports the overall trend that the shallowest gases are biogenic or mixed biogenicthermogenic, whereas the deeper gases all have a thermogenic origin.

Six gasbags were filled with gas from the open hole $(870-970 \mathrm{~m})$ in well $\mathrm{DH} 4$ and 5 gasbags from the open hole in well DH5R (645-701 m) (Fig. 3, Table 5). The high $\mathrm{i}-\mathrm{C}_{4} / \mathrm{n}-\mathrm{C}_{4}$ ratios for all the gases suggest that they are biodegraded as bacteria preferentially remove
$\mathrm{n}$-C4. However, the ratio is according to Leythaeuser et al. (1979) primarily controlled by kerogen quality. Type II kerogen generates significantly lower iso/nalkane ratios compared to type III kerogen. Methane concentrations are plotted versus isotope values in Fig. 8 , and suggest that the DH5R gas has a humic source. This may accordingly explain the high i-C4/n-C4 ratios of the sampled DH5R gas. Gas from the DH4 gasbags are suggested to have a marine, kerogen type II origin (Fig. 8 ) and consequently should demonstrate lower i-C4/ $\mathrm{n}-\mathrm{C} 4$ ratios. Isotope values of individual gas fractions are shown in Fig. 9. Katz et al. (2002) and Wang et al. (2005) show that biodegraded gases have 'peaks' (heavier isotope values) for propane and normal butane and lighter values for iso-butane. Non-degraded gases do not show this trend. Fig. 9 shows that gas from the DH4 gasbags has heavier propane and normal butane isotope values and lighter iso-butane, hence suggesting that the $\mathrm{DH} 4$ gas is biodegraded. This may explain the high $\mathrm{i}-\mathrm{C}_{4} / \mathrm{n}-\mathrm{C}_{4}$ ratio.

The plot of $\delta^{13} \mathrm{C}$ - ethane versus $\delta^{13} \mathrm{C}$-propane (Fig. 10) indicates the maturity of the source rocks that generated the gases. The plot suggests that the majority of gases sampled from the open-hole intervals in wells DH4 and DH5R came from source rocks in the maturity range 1.2 to $1.4 \%$ Ro. The relationship between isotopes and vitrinite in Fig. 10, however, is made for type II kerogen (Whiticar, 1994); thus, the suggested maturities for the DH5R gas, which has a humic source, may be hampered with more uncertainty than the DH4 gases. This may explain the large spread in maturity for the DH5R gases with end members at $0.9 \%$ and $1.7 \%$ Ro. Tmax versus hydrogen index (HI) for the Upper Jurassic sections in wells DH2 and DH5R are plotted in Fig. 11 on a background of 34 Barents Sea wells of various maturity stages downloaded from the Norwegian Petroleum Directorate's FactPages. It is clear that the analysed Agardhfjellet source-rock intervals in wells $\mathrm{DH} 2$ and DH5R are mostly in the wet gas maturity window. This is similar to the gas maturities suggested for the $\mathrm{DH} 4$ and DH5R gases in Fig. 10. This maturity range fits well with data from Abay et al. (2017) who analysed residual oil in the same stratigraphic interval that tested gas in well DH4, and concluded that it originated from a Middle Triassic source rock at the end of the oil window. The maturity trend for the area is visualised in Fig. 12 with vitrinite values plotted versus depth for well $\mathrm{DH} 4$ and Tmax values versus depth plotted for wells $\mathrm{DH} 2$ and

Table 3. Summary of gas encountered in the UNIS $\mathrm{CO}_{2}$ lab wells. The stratigraphic positions of the gas are highlighted in Fig. 3.

\begin{tabular}{lccc}
\hline \multicolumn{1}{c}{ Gas discovery } & Well name & Depth interval of sample & Stratigraphic interval \\
\hline Shallow, sub-permafrost gas & DH4 & $<150 \mathrm{~m}$ & Helvetiafjellet Fm \\
Shale gas & DH5R, DH7A & $645-701 \mathrm{~m}$ & Agardhfjellet Fm \\
Deep gas & DH4 & $870-970 \mathrm{~m}$ & De Geerdalen Fm \\
\hline
\end{tabular}




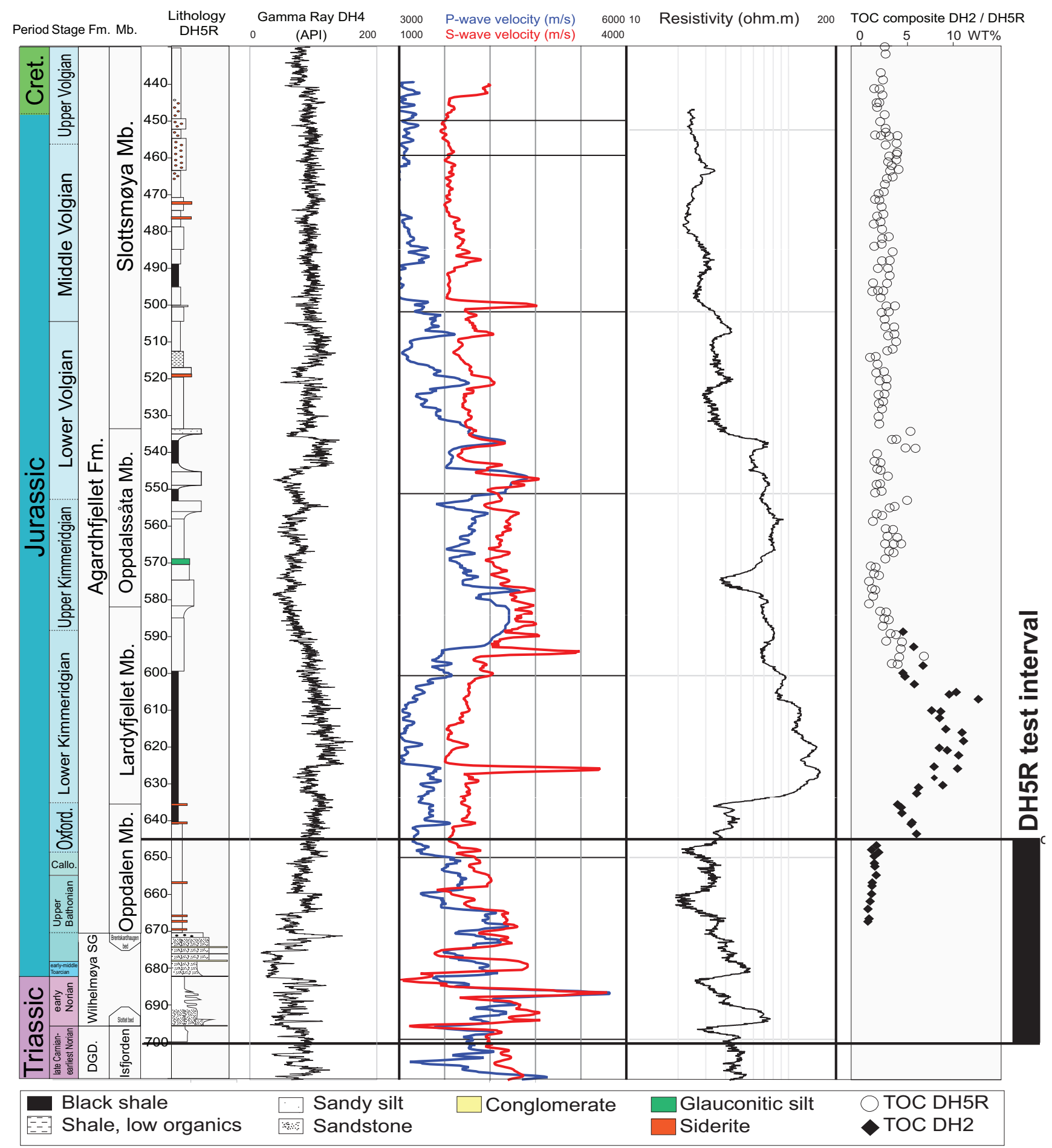

Figure 5. Detailed stratigraphic chart of the tested interval in DH5R complemented by a wireline log suite in the nearby DH4 borehole as the DH5R borehole was not logged for resistivity and velocity in this section (Well site DH4 is $50 \mathrm{~m}$ west of DH5R). Stratigraphy, sedimentary log and the TOC data are from Koevoets et al. (2019), Rismyhr et al. (2019) and Mulrooney et al. (2019). Wireline data from the Geological Survey of Norway (Elvebakk, 2010). DG - De Geerdalen Formation.

DH5R. The vitrinite data support $2.5-3 \mathrm{~km}$ of uplift and erosion.

The star plot diagram (Fig. 13) clearly differentiates gases from wells DH4 and DH5R based on composition and isotope values of individual gas fractions. Both gases are dry with methane concentrations $>90 \%$. The DH4 gases from the De Geerdalen Formation contain less methane and higher concentrations of ethane through butane, which is to be expected as the tested interval also contains residual oil (Abay et al., 2017). The DH4 gases are also isotopically lighter than the DH5R gases. These differences, based on the previous discussion, reflect different origins for the gases. The DH5R gas is believed 
(ui) uzdəa

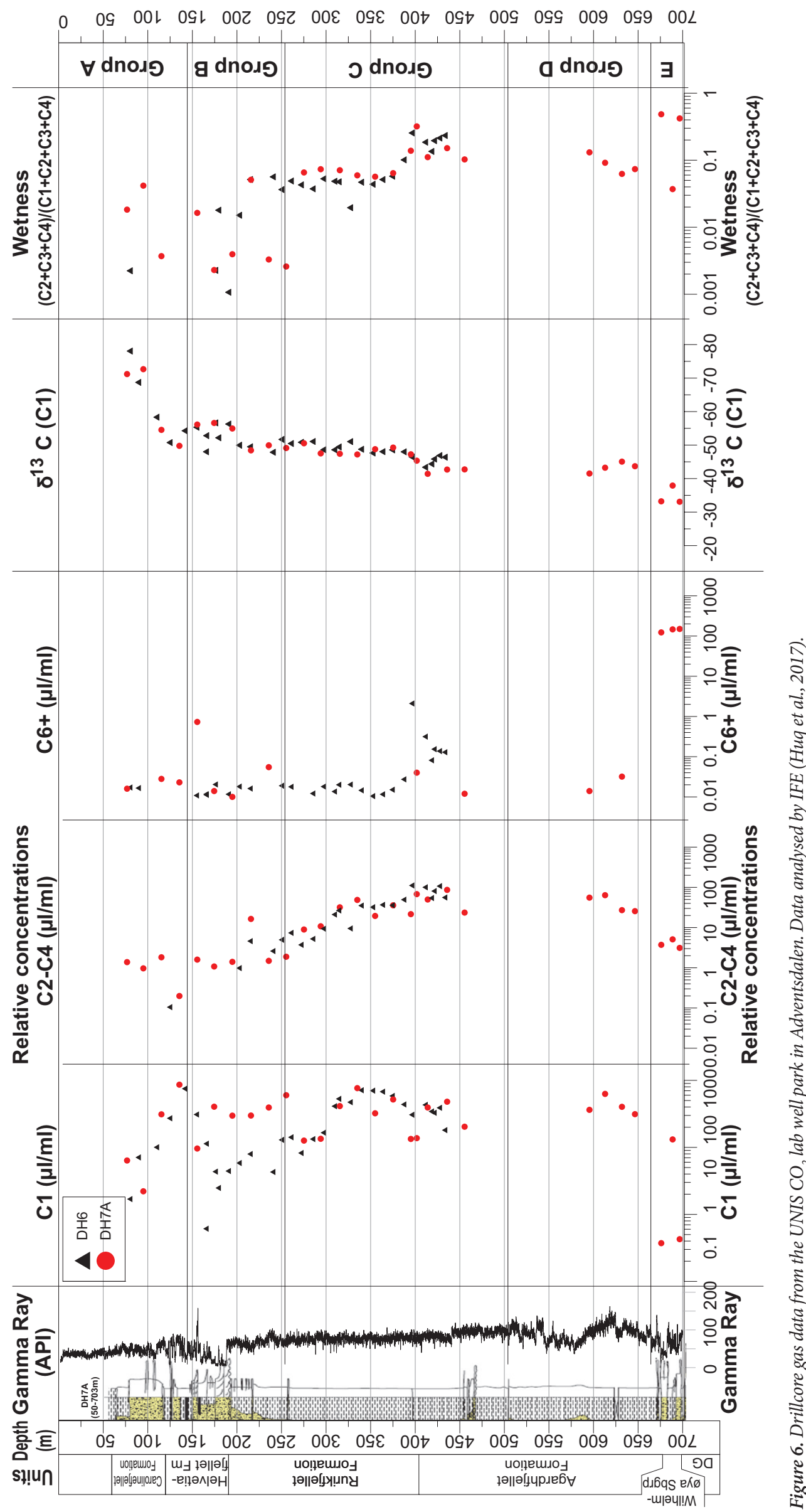




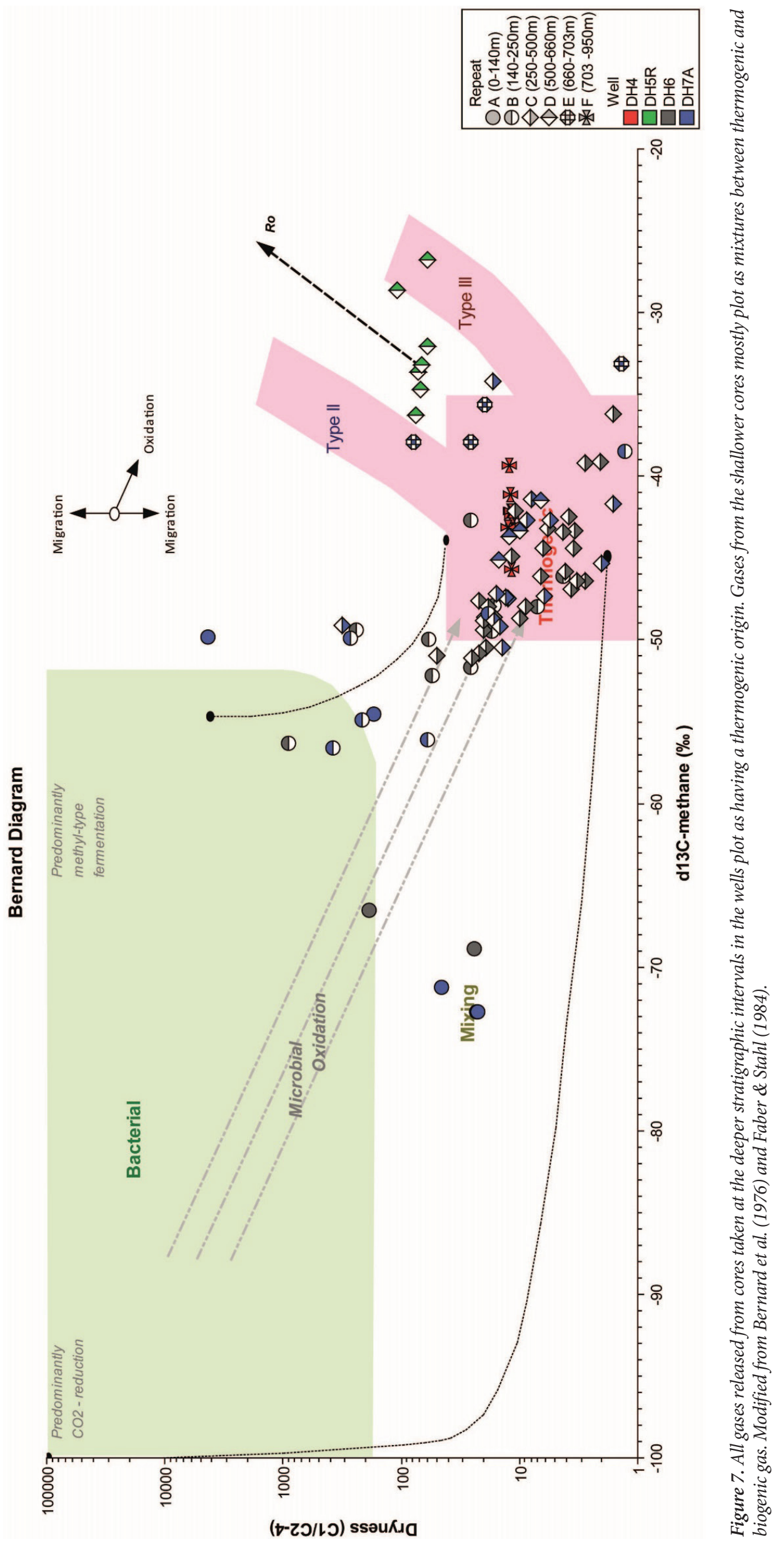




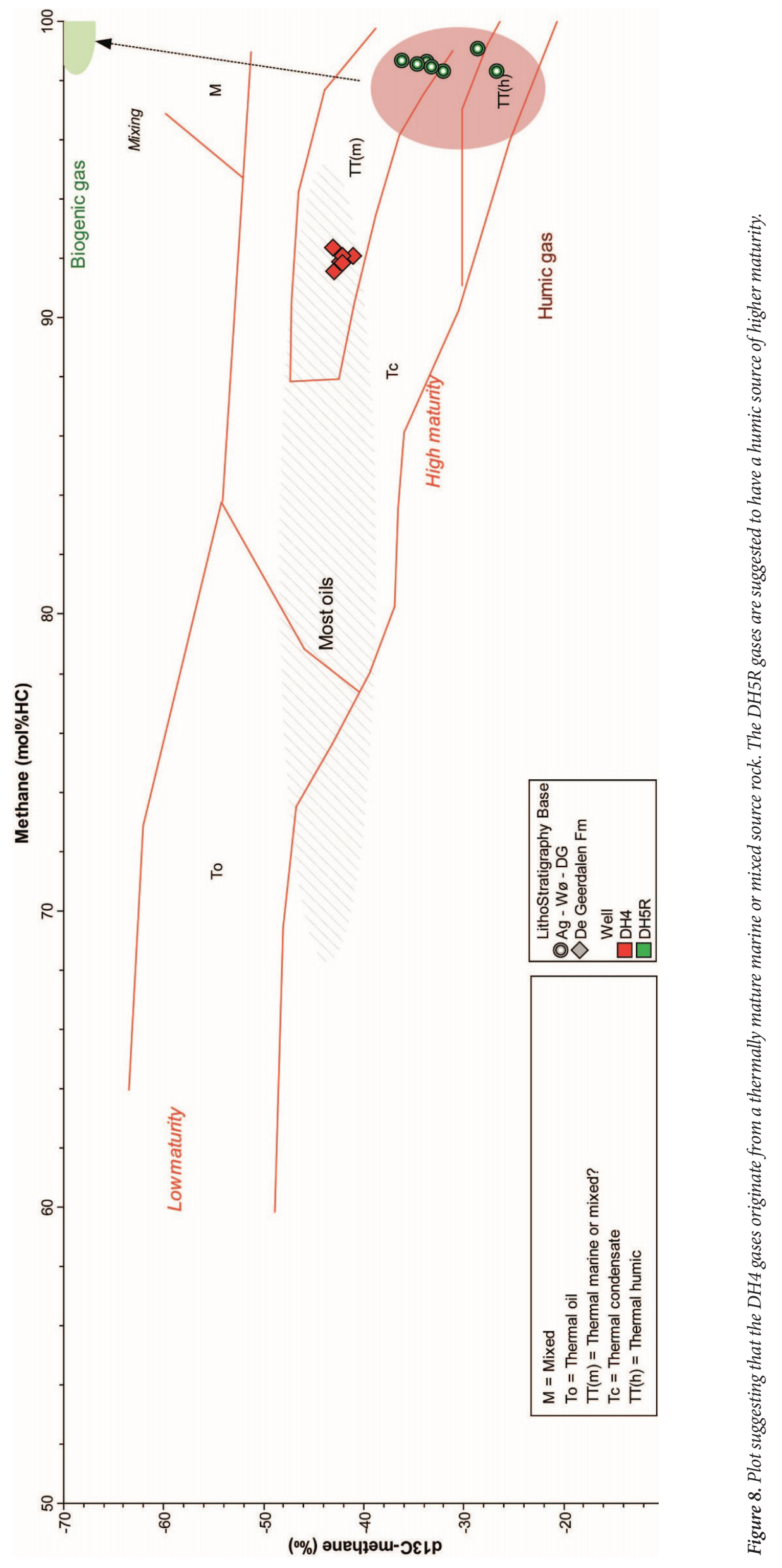




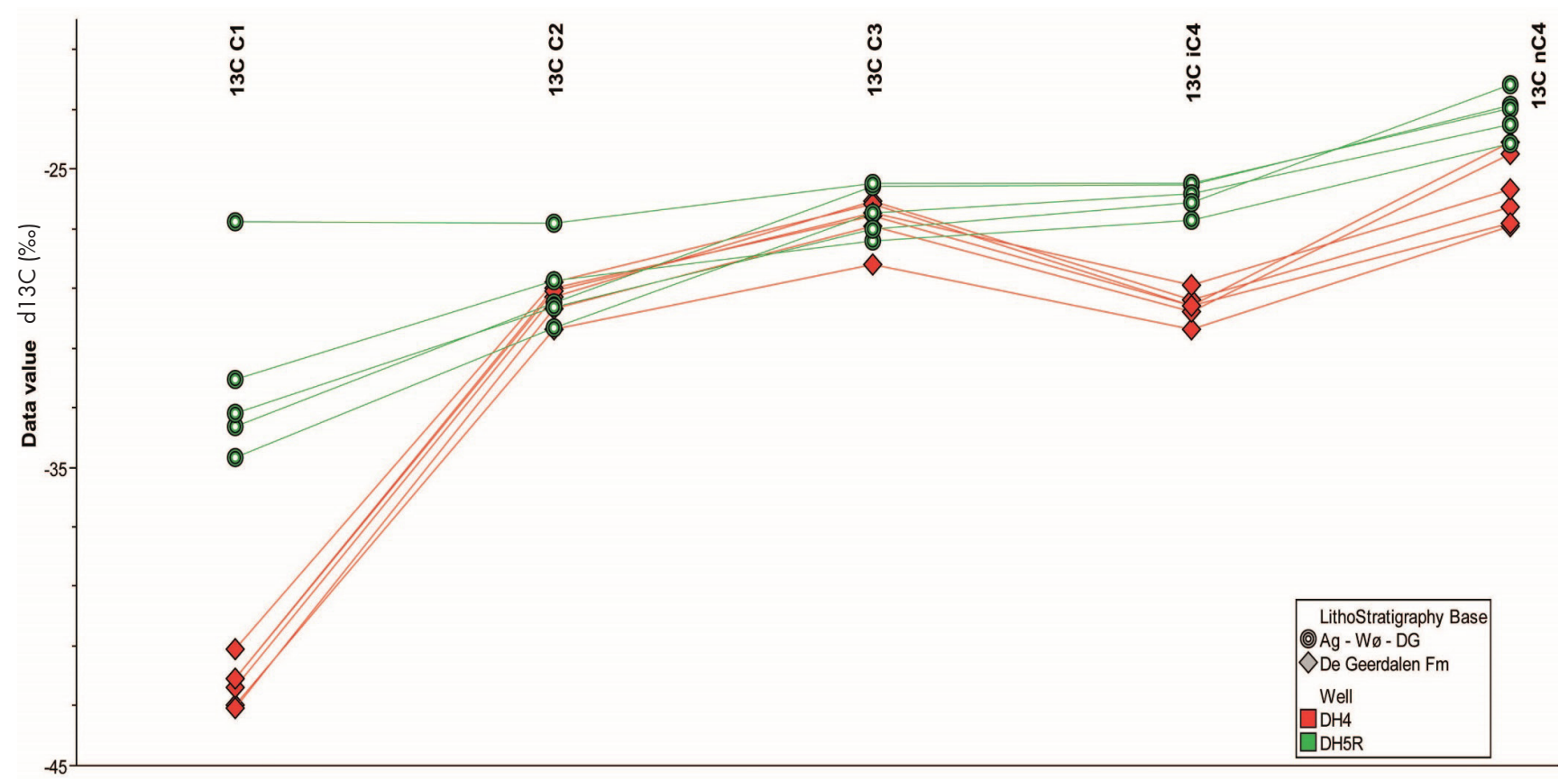

Figure 9. Isotope values of individual HC gas components fractions from wells DH4 and DH5R. The relatively heavier isotope values seen for propane (C3) and normal butane $\left(n-C_{4}\right)$ from the DH4 gasbags suggest that the gases are biodegraded (Whitaker, 1994). The DH5R gases do not show this trend and are not believed to be biodegraded.

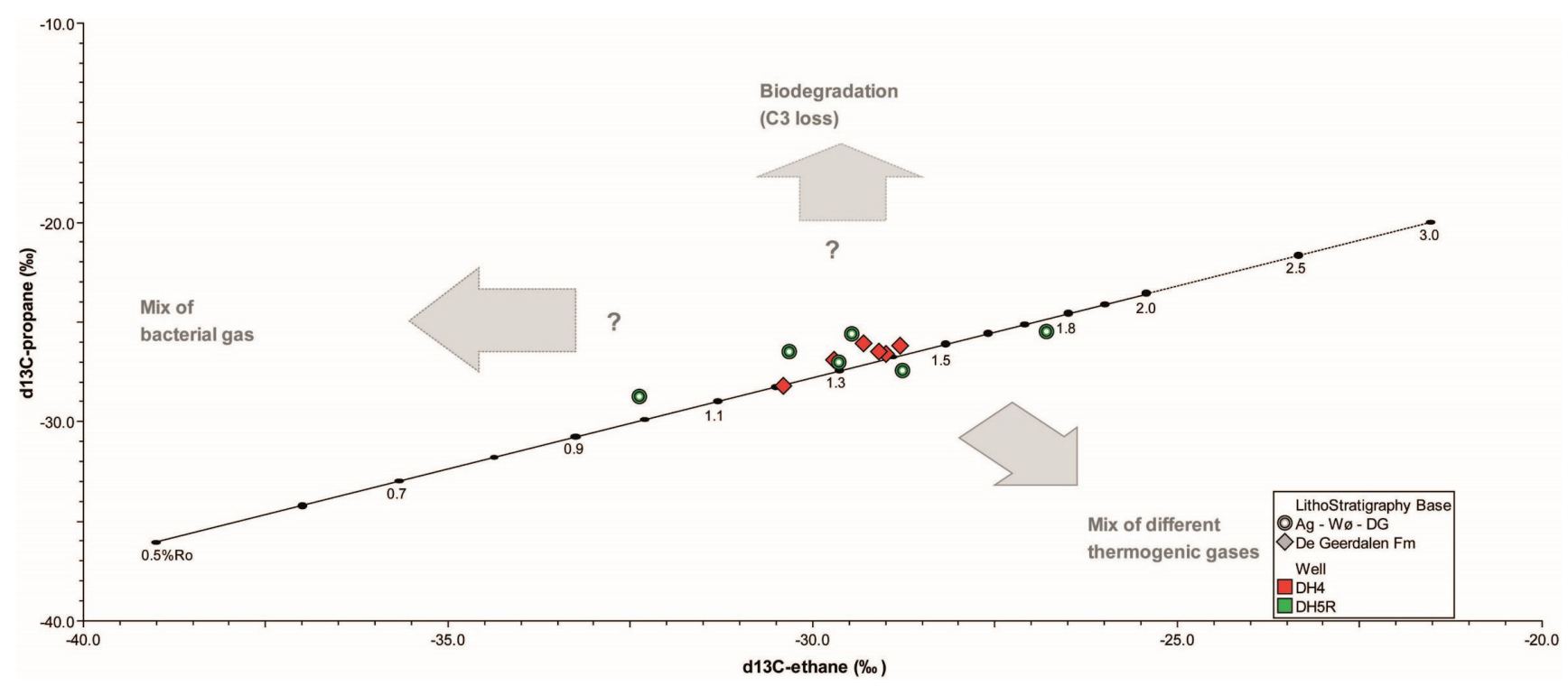

Figure 10. Plot modified after Berner \& Faber (1996) suggesting the maturity of the source rock that generated and expelled the gases. All samples were sampled from open hole; DH5R from the lowermost Agardhfjellet to De Geerdalen Formation (645-701 $\mathrm{m}$ interval) and DH4 from the De Geerdalen Formation $(870-970 \mathrm{~m})$.

to be in situ gas from the Agardhfjellet Formation released by formation of radiant fractures induced by the leak-off test in the 645-648 m interval (Figs. 3A \& 4). The DH4 gas has migrated to its present location from a marine type II kerogen, which was at the same maturity as the present-day maturity of the source rock expelling the DH5R gas.
Surface sediments collected from fjords on Svalbard contain a mixture of thermogenic and biogenic gas consisting of methane with some ethane and minor concentrations of $\mathrm{C}_{3+}$ (Liira et al., 2019). The thermogenic fraction of these gases originate from gasmature source rocks belonging to the Middle Triassic Botneheia and Upper Jurassic Agardhfjellet Formations. 


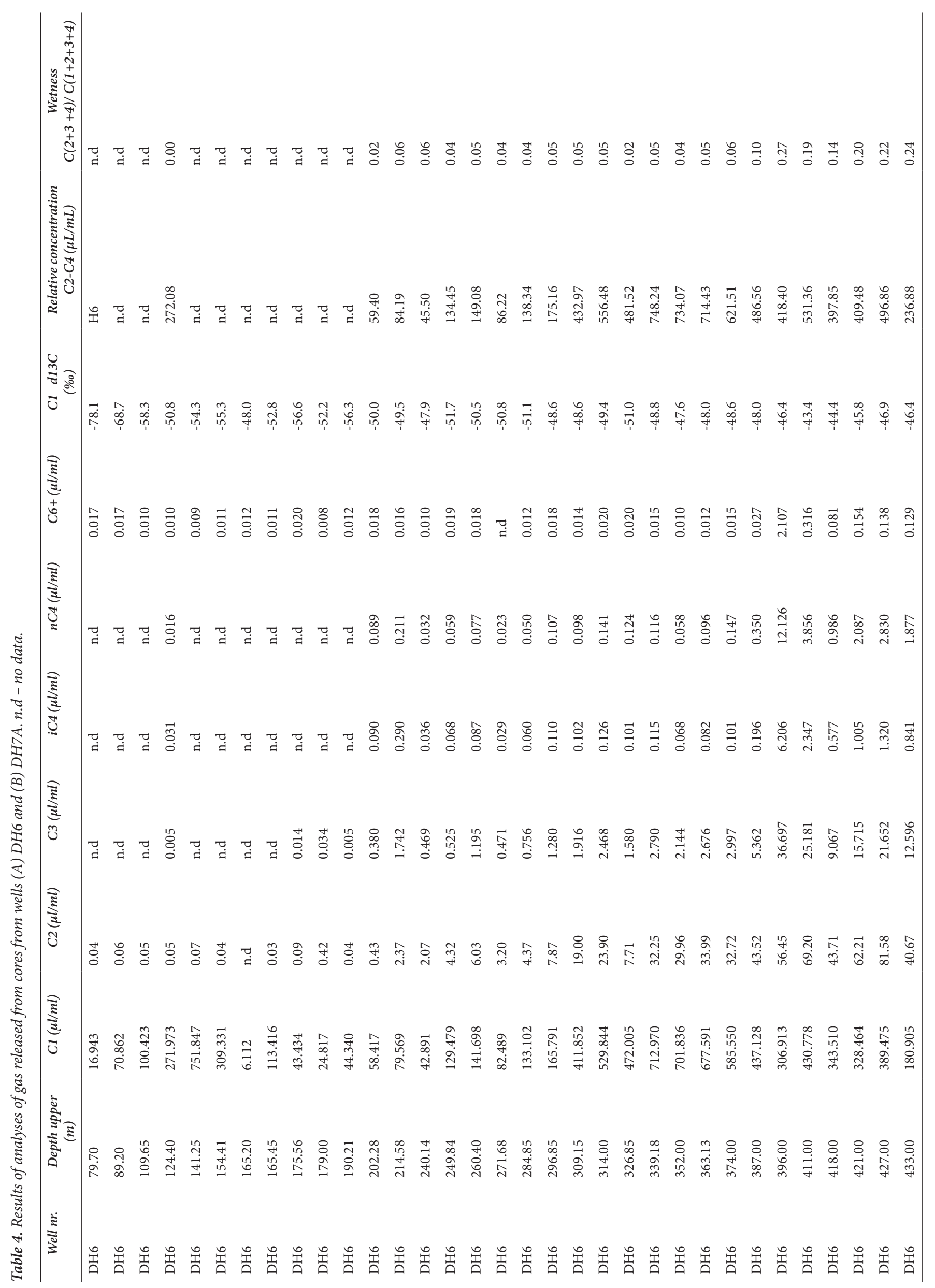




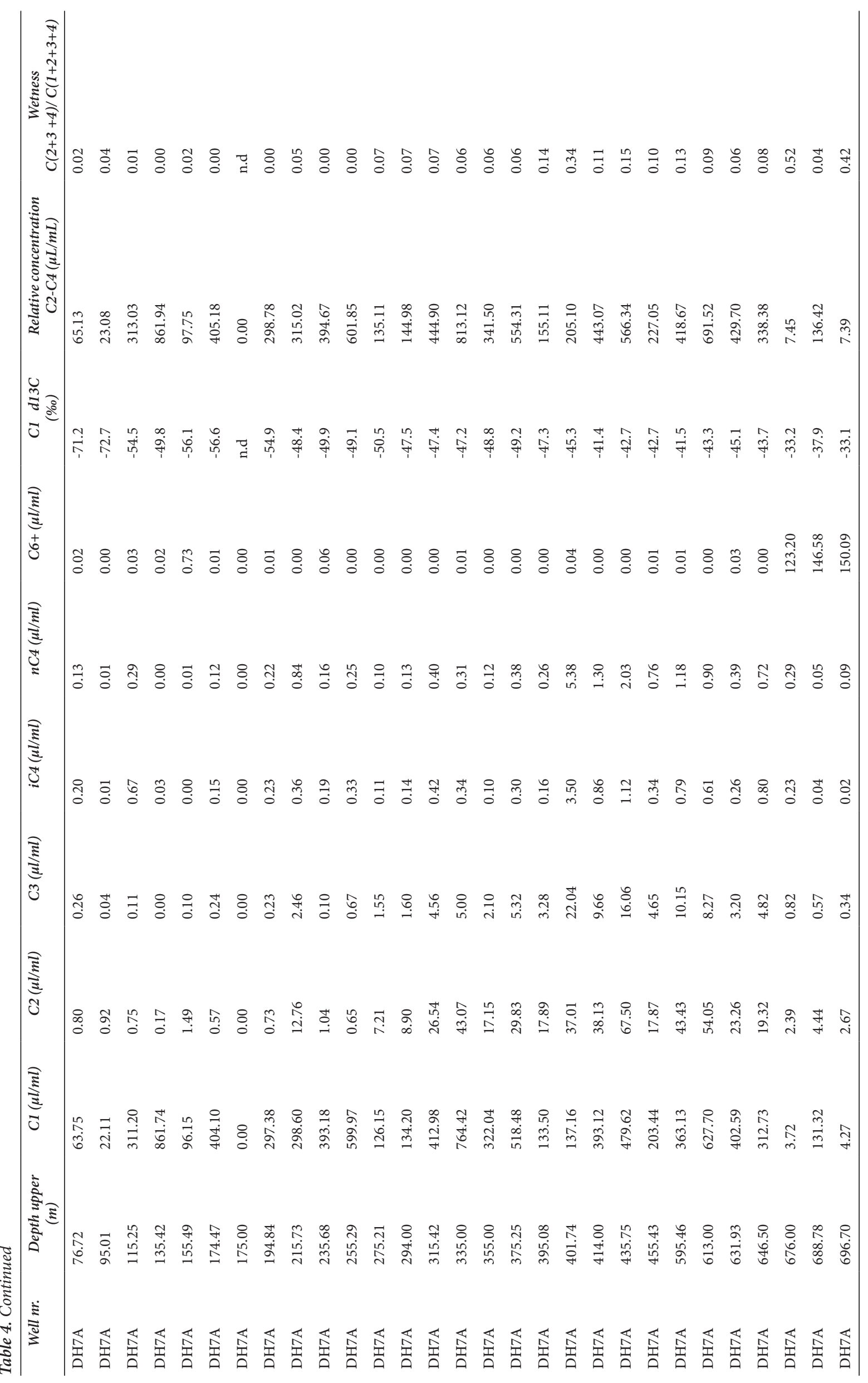




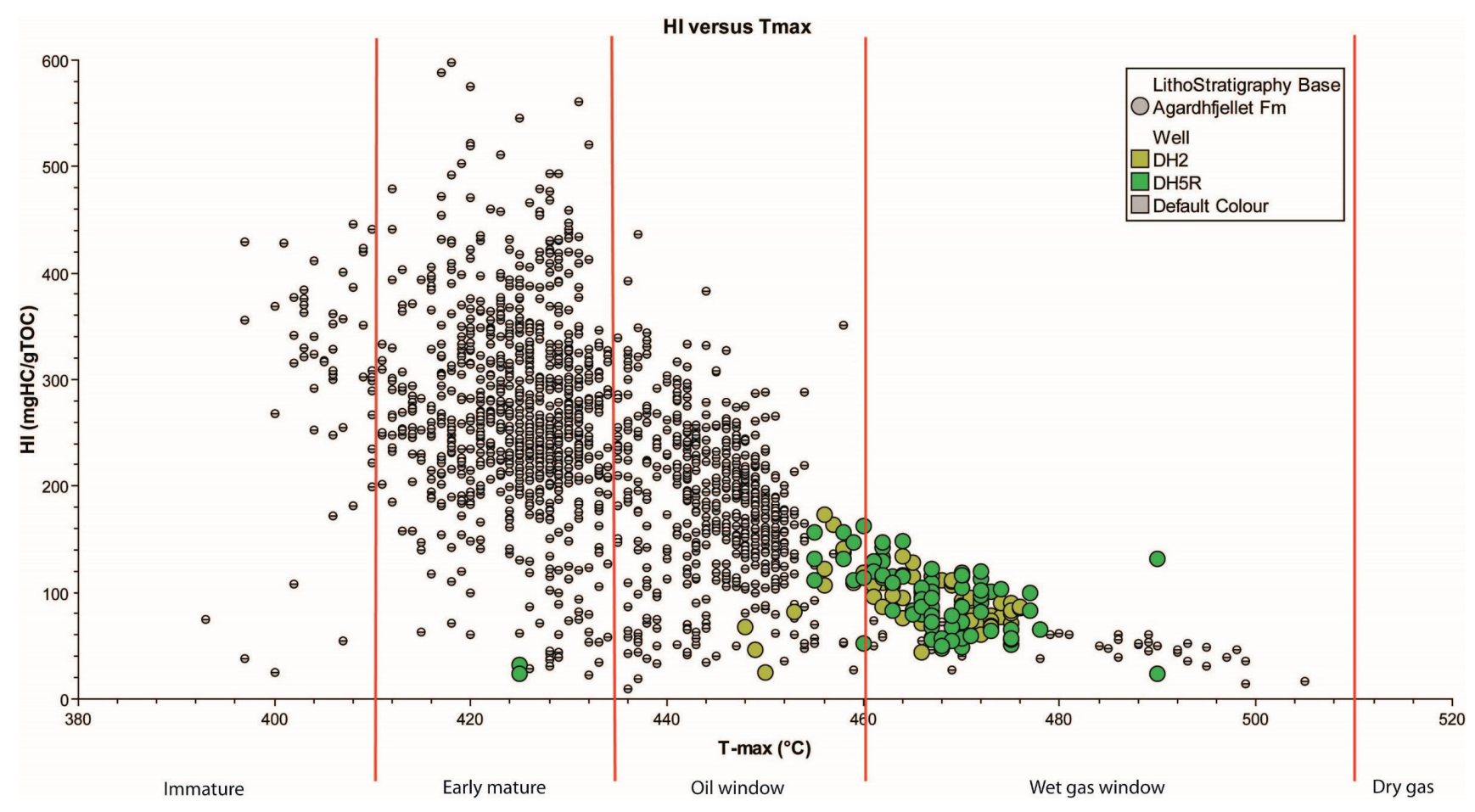

Figure 11. Tmax versus hydrogen index (HI). Maturity intervals are indicated along the Tmax axis. The values plotted with grey colour represent Upper Jurassic data from 39 Barents Sea wells downloaded from the NPD fact pages. The samples from the DH2 and DH5R Upper Jurassic Agardhfjellet Formation source-rock intervals plot on the high mature end of the Barents Sea data and are suggested to be in the wet gas window.

\section{Maceral compositions}

The maceral composition of four samples from the Agardhfjellet Formation in DH5R were analysed and indicate that the Agardhfjellet Formation contains a mixture of type II and type III kerogen (Fig. 14). The most fine-grained interval shows a higher TOC content and consists of kerogen type II, whereas the more silty intervals have a lower TOC content and higher vitrinite content, corresponding to type III kerogen. The analysed DH5R gas, which is suggested to have a humic, kerogen type III source, hence represents the siltier part of the Agardhfjellet Formation. The high content of solid bitumen seen in the middle part of the $40 \mathrm{~m}$-thick lower shale sequence (Fig. 14) correlates with the highest TOC content and may reflect the presence of non-expelled petroleum. This could be linked to the lower quartz content in the middle part of this shale interval, which makes it less brittle and consequently less likely to fracture during pressure build-up related to maturation of the source rock (Table 1) (Cardott, 2012).

\section{Test data and gas-flow properties from well DH5R}

More than 22 months of pressure data exist from the DH5R borehole after the water had segregated below the gas source, and the well could be considered as a gas producer. Most of the data cover extended shut-in periods between gauge-retrieval operations. With positive pressure at the well head it was necessary to bleed off the pressure before the gauge could be pulled to download pressure data, change battery and reset the gauge. Except for some controlled operations with a mounted in-line gas-flow meter in August 2013, the gas was flared to drawdown the pressure without rate measurements (Figs. 3B \& 4). Nevertheless, based on two flow periods with declining rates over approximately 6 hours (August 2013), and pressure data from the following shut-in periods, we have a good basis to determine the flow capacity (permeability-thickness product) of the formation contributing the gas flow. From the characteristics of the pressure recovery after shutins, it was clear that the formation had to be bounded by nearby faults or other flow barriers. One nearby pressure boundary is consistent with an interference test between wells DH7A and DH5R where no pressure response was observed, but just one boundary is not sufficient to match the pressure data (Mulrooney et al., 2019).

A long and narrow, $5 \mathrm{~m}$-thick, rectangular drainage area (Fig. 15A) with permeability $0.5 \mathrm{md}$ and the well located near one end was found to closely match the pressure buildups with flow rates consistent with the August 2013 data. The distances are small: 17 and $34 \mathrm{~m}$ to the sides, $8 \mathrm{~m}$ to the end, and at least $600 \mathrm{~m}$ to the most distant boundary. The gas composition used in analyses and in forecasts to generate key PVT parameters is 97\% methane and 3\% ethane.

As discussed above, the formations are significantly under-pressured. From the DH5R gas-flow data a 


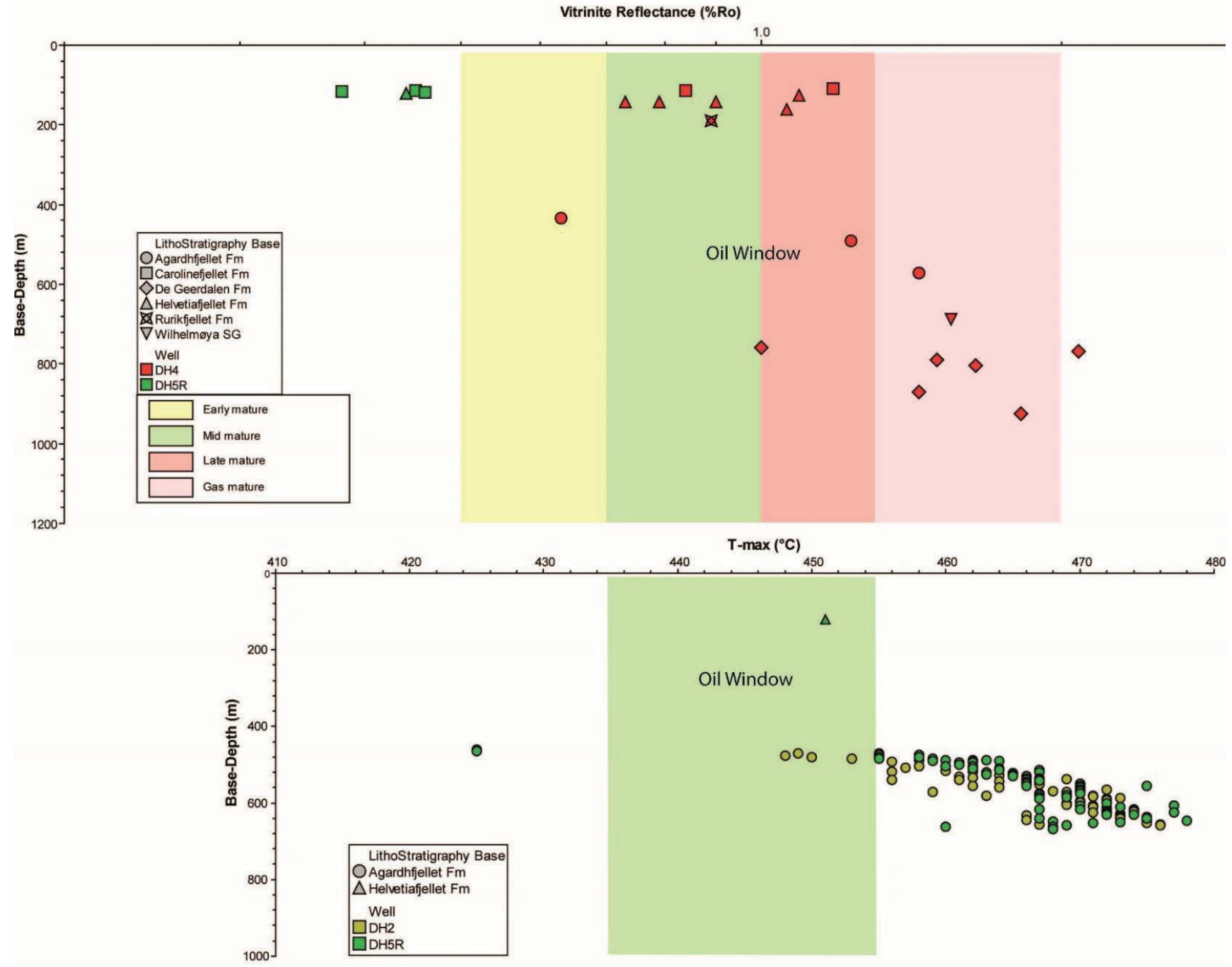

Figure 12. Maturity plots showing vitrinite reflectance and Tmax versus depth. The upper Ro plot is aligned with the lower Tmax plot to reflect roughly the same maturity ranges.

formation pressure of 28.9 bar has been estimated along with a temperature of $24^{\circ} \mathrm{C}$ at a depth of $645 \mathrm{~m}$.

In addition to the rectangular boundaries it has also been necessary to use a negative skin value at the well to compensate for less pressure drop at the well than what radial flow all the way to the small borehole would imply. This is consistent with a short hydraulic fracture with half-length $2.7 \mathrm{~m}$ (full length $5.4 \mathrm{~m}$ ) at the well. Following an initial leak-off test in the shale (Figs. 3A \& 4), the existence of a fracture is considered realistic.

\section{Forecasting shale gas production}

Potential production forecasts of shale gas from the Agardhfjellet Formation using two scenarios based on a) the vertical DH5R borehole and b) on optimised horizontal producers.

\section{Scenarios based on DH5R properties}

Based on the test results from well DH5R, production forecasts were run directly from the analysis model and from more productive scenarios. From the basic model with a $5 \mathrm{~m}$-thick interval and nearby boundaries, the production declines rapidly as it is expected from such a narrow flow model with the well located near one end of the drainage area. Forecasts were also generated for a square model with sides of length $2000 \mathrm{~m}$ and a fractured well at the centre using the same model parameters in order to determine the effects of fracture length on production (Fig. 15). It was examined how production performance might be enhanced if a multi-fractured horizontal well is used as in shale gas operations onshore USA (Curtis, 2002). Of course, if boundaries are present throughout the interval, then additional drainage points will be required to match the single-well performance of the open model.

All scenarios were run with the same initial pressure of 28.9 bar and flow at a constant bottom-hole pressure (operating pressure) of $10 \mathrm{bar}$ and declining rate. With lower pressure the rate will increase to some degree, proportional to the added drawdown. With added 
formation thickness, the rate and production will increase with the same ratio if the flow properties are similar. Otherwise, there will be some correlation with the change in properties.

The production forecasts were generated for 4000 days (almost 11 years), starting with the model used in analyses of the DH5R (Fig. 15B) data with the most distant boundary at $1200 \mathrm{~m}$ (Fig. 15A). In order to properly observe the rate decline with time, a logarithmic rate scale has been used, while the cumulative produced gas volume is shown on a linear scale. The forecast shows that the single well 'high' gas rates between 2500 and $1500 \mathrm{Sm}^{3} /$ day recorded from DH5R at pressures declining towards 10 bar, cannot be sustained for very long. Model gas rates over $100 \mathrm{Sm} 3$ /day are only expected for about 7 months. The main reason for the rapid rate decline from the DH5R model is the shape of the drainage area-a long rectangle of width $51 \mathrm{~m}$ with the nearest end only $8 \mathrm{~m}$ from the well. However, if the drainage area is changed from the long and narrow rectangle to a large square with sides of length $2000 \mathrm{~m}$ without changing the flow properties and operating pressure, the situation changes significantly as shown in Fig. 15C. This case was generated with a single infiniteconductivity fracture with a half-length of $2 \mathrm{~m}$, which is a little shorter than the fracture half-length of $2.7 \mathrm{~m}$ used in the DH5R model. At the end of the forecasts (11 years) the produced volume was 13.7 times higher and the rate 27 times higher (584 vs. $21.6 \mathrm{Sm}^{3} /$ day) for the square drainage area compared to the narrow rectangle. The difference in area is 4 million vs. $61,608 \mathrm{~m}^{2}$ for the two models. The square drainage area is therefore 65 times larger than the rectangular area.

For the same square model the data in Fig. 15D show how the performance is affected by different half-lengths for the fractured well. The cases shown are based on selected half-lengths (xf) of: $1,2,4,8,16,32,64,128$ and $256 \mathrm{~m}$, all with infinite conductivity. The plot shows a significant improvement in production with even a moderate half-length of $64 \mathrm{~m}$, with a doubling of the case with a fracture half-length of $2 \mathrm{~m}$.

Two advanced, multi-fractured, horizontal well cases (MFHW 1 and MFHW 2) have also been included for reference. Layouts of these are shown in Fig. 16A. The MFHW 1 case has 10 infinite-conductivity fractures with half-lengths of $100 \mathrm{~m}$ that are evenly distributed along a centered horizontal well of length $500 \mathrm{~m}$. The MFHW 2 case has the same number of fractures as MFHW 1, but with half-lengths of $200 \mathrm{~m}$ evenly distributed along a well of length $1000 \mathrm{~m}$. An important objective of such completion scenarios is improved formation exposure in the sense of reducing flow distance from the formation to the well or fracture system, and thereby increasing the gas production. This is clearly the case for the MFHW 2 scenario relative to MFHW 1 (Fig. 16B). While the gas production in the MFHW 1 case is not much different

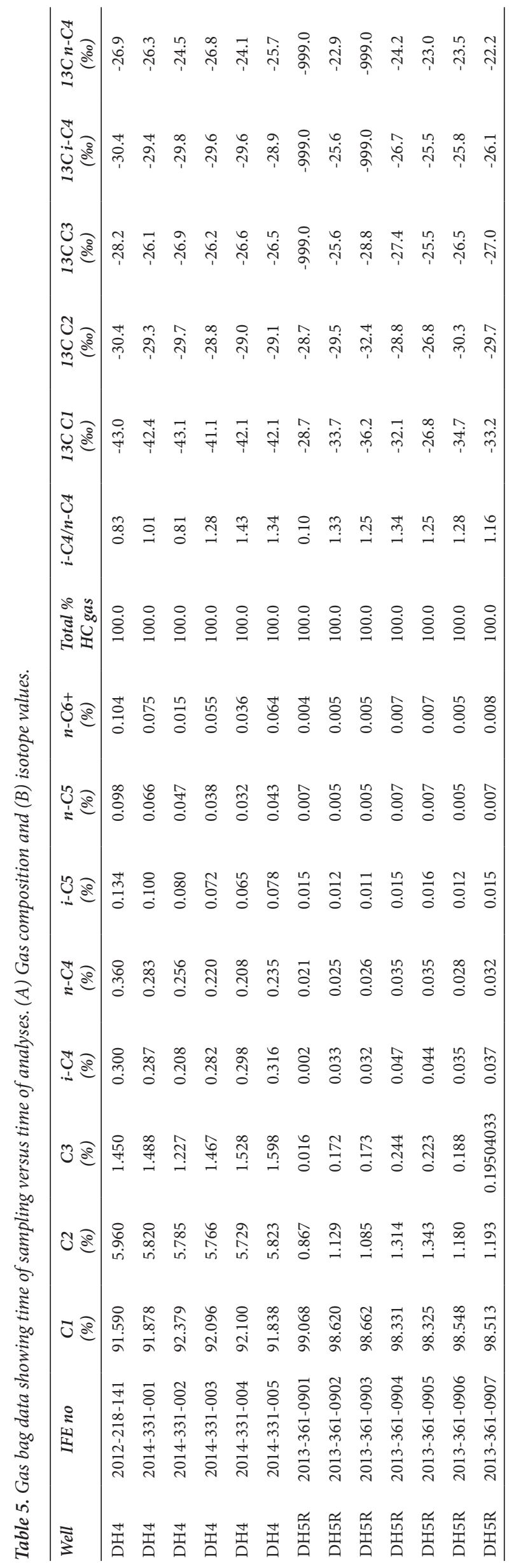




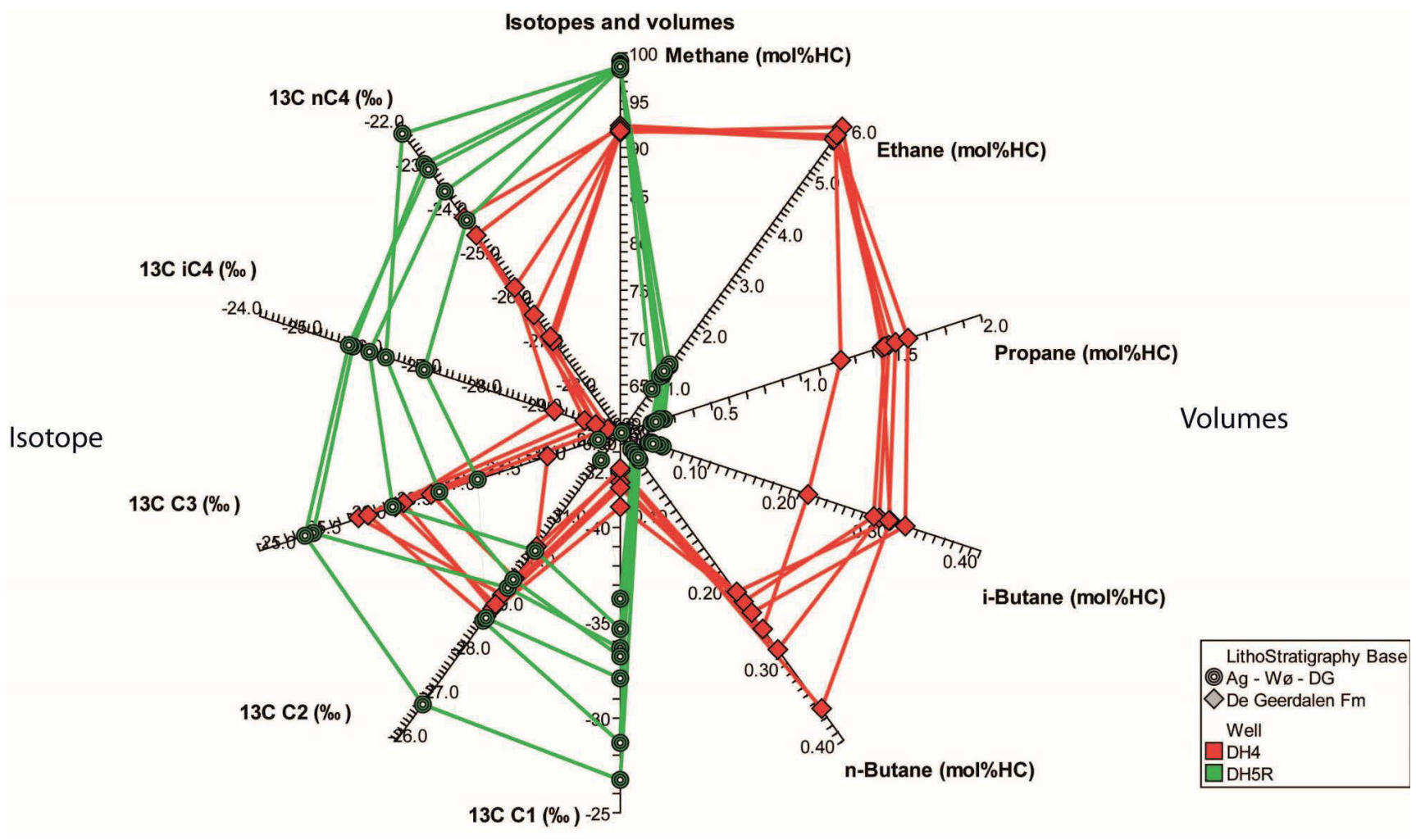

Figure 13. Star diagram differentiating the DH4 gases coloured red from the DH5R gases coloured green. The DH5R gases are drier than the DH4 gases whereas the latter are isotopically lighter. The figure clearly separates the DH4 from the DH5R gases, which were sampled in gas bags.

from a single fracture with a half-length of $256 \mathrm{~m}$, the MFHW 2 case shows a much higher production. For lowpermeability formations it might be critical to reduce the flow distance with multi-fractured wells with formation exposure similar to the MFHW 2 scenario or better, but not necessarily for cases with permeability as high as that obtained from the DH5R data. The choice will depend on the required rates. Fig. 16B illustrates how much the production can be increased by choosing multi-fractured horizontal wells compared to single-fracture vertical wells. The main difference is in the early data, with the MFHW 2 case enabling much higher initial production.

Although multi-fractured horizontal wells can be efficient producers, similar performance can be matched with the cumulative production from multiple fractured vertical wells. Fig. 16C illustrates this point by comparing the MFHW 2 case with a case with one well in each quadrant, each fractured with the same half-length of $200 \mathrm{~m}$ as for the scenario with 10 MFHW 2 fractures. With more fractures, MFHW 2 operates at a higher rate initially, but only for about 30 days (not visible in Fig. 16C). Until about 2200 days (6 years), the vertical wells operate at a higher rate than the MFHW 2. After this, the MFHW 2 again operates at a higher rate because the 4 wells have lowered the formation pressure much more in the cases characterised by reasonably high permeability and shallow formations. Therefore, vertical wells are likely more economical, and definitely a more robust option.
An important indicator of the production efficiency of the different completion scenarios is the change in average pressure over time, but this has to be viewed along with the rate. Fig. 16D shows, for instance, that the DH5R model is quite efficient in terms of producing the in-place volume, but at a relatively low rate.

\section{Scenarios with thicker and more productive formations}

As has already been pointed out, the production is directly proportional to the thickness of the formation. For early data, the production can also be considered to be proportional to the permeability, but the cumulative production is controlled by the pore volume and compressibility, thus higher permeability first of all enables accelerated production.

Fig. 16E illustrates some scenarios comparing production forecasts from single fractured wells in formations with thicknesses of 5 and $30 \mathrm{~m}$, and permeability of $0.5 \mathrm{md}$ and $1 \mathrm{md}$, respectively. The drainage areas are both squares with sides of length $2000 \mathrm{~m}$. The fracture half-length is $100 \mathrm{~m}$ in the $1 \mathrm{md}$ formation and $200 \mathrm{~m}$ in the $0.5 \mathrm{md}$ formation, with longer fractures selected to compensate for the lower permeability. The results shown in Fig. 16E are as expected, with a more than 6 -fold increase in production going from a 5 to a 30 $\mathrm{m}$-thick formation, but not a 12 -fold increase $(30 \mathrm{~m} / 5$ 

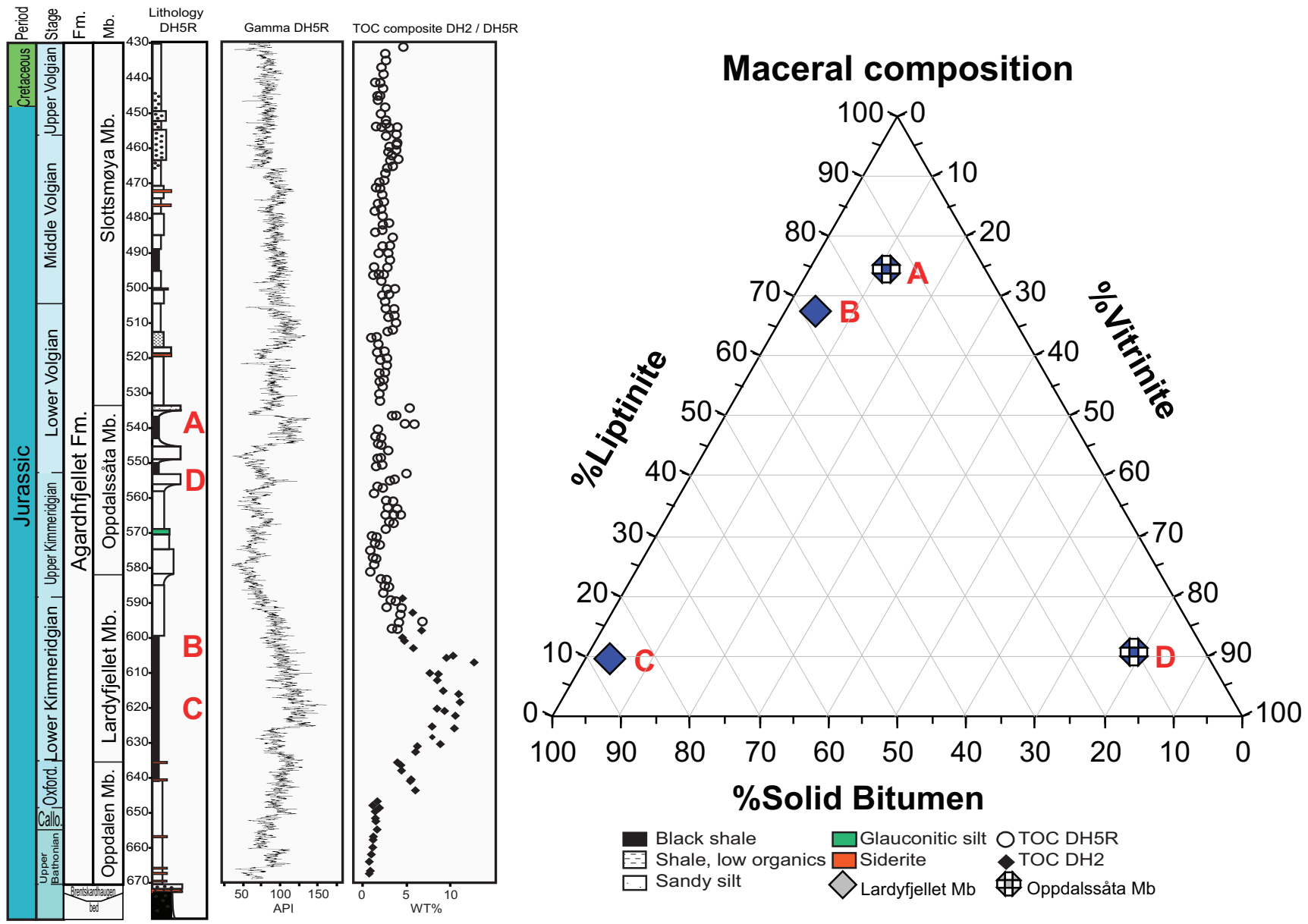

Figure 14. Maceral composition linked to detailed stratigraphy and TOC measurements of the Agardhfjellet Formation as presented by Koevoets et al. (2018). Samples A and B are representative of kerogen type II, while sample D represents kerogen type III. Sample C shows a high content of solid bitumen, which correlates with the highest TOC of the shale. This may represent non-expelled petroleum.

Table 6. Overview of production scenarios tested.

\begin{tabular}{ll}
\hline \multicolumn{1}{c}{ Model name } & \multicolumn{1}{c}{ Key model parameters } \\
\hline DH5R rectangular & $\begin{array}{l}\text { Single vertical well with a short fracture (half-length } 2.7 \mathrm{~m} \text { ) located near one end of a } 51 \text { by } 608 \mathrm{~m} \\
\text { rectangular drainage area of thickness } 5 \mathrm{~m} \text { and permeability of } 0.5 \mathrm{mD}\end{array}$ \\
DH5R square & $\begin{array}{l}\text { Single vertical well with fracture half-lengths varying from } 1 \text { to } 256 \mathrm{~m} \text { at the centre of a } 2000 \text { by } 2000 \mathrm{~m} \\
\text { square drainage area of thickness } 5 \mathrm{~m} \text { and permeability } 0.5 \text { of } \mathrm{mD}\end{array}$ \\
MFHW1 & $\begin{array}{l}\text { Single } 500 \mathrm{~m} \text { horizontal well with } 10 \text { evenly spaced fractures of half-length } 100 \mathrm{~m} \text { at the centre of a } 2000 \text { by } \\
2000 \mathrm{~m} \text { square drainage area of thickness } 5 \mathrm{~m} \text { and permeability of } 0.5 \mathrm{mD}\end{array}$ \\
MFHW2 & $\begin{array}{l}\text { Single } 1000 \mathrm{~m} \text { horizontal well with } 10 \text { evenly spaced fractures of half-length } 200 \mathrm{~m} \text { at the centre of a } 2000 \\
\text { by } 2000 \mathrm{~m} \text { square drainage area of thickness } 5 \mathrm{~m} \text { and permeability } 0.5 \mathrm{mD}\end{array}$ \\
4 vertical wells & $\begin{array}{l}\text { Four fractured vertical wells with half-lengths of } 200 \mathrm{~m} \text { in a } 2000 \text { by } 2000 \mathrm{~m} \text { square drainage area of } \\
\text { thickness } 5 \mathrm{~m} \text { and permeability of } 0.5 \mathrm{mD} \text { treated as one well (one well in each quadrant) }\end{array}$ \\
Vertical well & $\begin{array}{l}\text { Single vertical well with half-length } 100 \mathrm{~m} \text { at the centre of a } 2000 \text { by } 2000 \mathrm{~m} \text { square drainage area of } \\
\text { thickness } 30 \mathrm{~m} \text { and permeability } 1 \mathrm{mD}\end{array}$ \\
\hline
\end{tabular}

$m *$ twice the permeability) since a longer fracture in the $5 \mathrm{~m}$ thick formation compensates to some degree for the lower permeability. Table 6 provides an overview of the various models tested. 


\section{A) DH5R scenario: Well $8 \mathrm{~m}$ from one end and 17 and $34 \mathrm{~m}$ from the sides of a narrow rectangle of total length $1208 \mathrm{~m}$ (fracture with half-length $2 \mathrm{~m}$ inside well marker)}
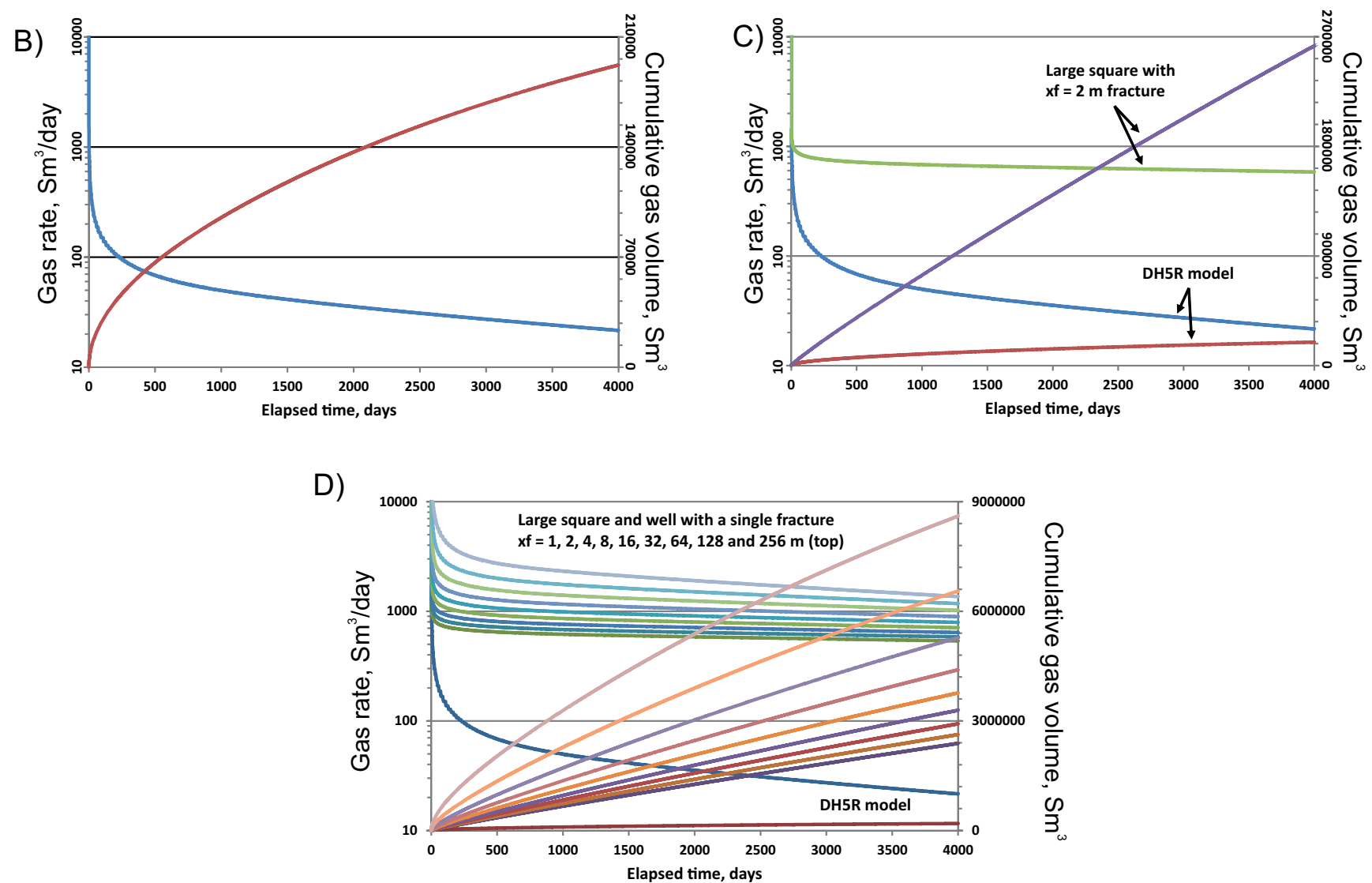

Figure 15. Predicted production forecasts using vertical wells. (A) Geometry of the DH5R rectangular model. (B) Production forecast for the DH5R rectangular model with the blue curve showing rate and the red curve produced volume. (C) Production forecasts from the DH5R model and from a large square model with a centered well with a short fracture half-length of $2 \mathrm{~m}$. (D) Sensitivity of the fracture half-length on production forecasts from the square model compared with the production forecast from the DH5R model.

\section{Discussion}

Regional implications of the Adventdalen shale gas discovery

Petroleum exploration onshore Svalbard resulted in the drilling of eighteen wells in the period from 1961 to 1994 targeting conventional petroleum systems (Nøttvedt et al., 1993b; Senger et al., 2019). The majority of the boreholes were drilled on the basis of surface mapping, while only three were placed on the basis of $2 \mathrm{D}$ seismic data. Apart from the poor reservoir quality, the definition and size of traps were considered as the most significant risk elements (Nøttvedt et al., 1993b). While no commercial petroleum accumulations were encountered, more than half of the wells encountered gas shows, some in measurable quantities (Senger et al., 2019). Many of these were stratigraphically associated with organic-rich shales in the Middle Triassic (Botneheia/Bravaisberget formations), but a shale gas accumulation from the Upper Jurassic Agardhfjellet Formation was reported from the 7617/1-1 Tromsøbreen-I well (NPN, 1977).

Fig. 2 shows a structural contour map of the Agardhfjellet Formation, indicating its gradual deepening towards the southwest. The Agardhfjellet Formation acts as the uppermost of three major décollement zones characterised by thin-skinned tectonism associated with the formation of the WSFTB (Bergh et al., 1997; Braathen et al., 2012). Thrusts, back-thrusts and duplex structures are commonly associated with this décollement zone and the overlying 
A)
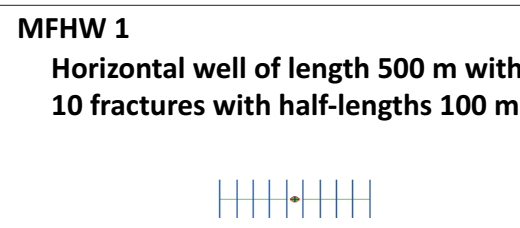

Square drainage area with sides of length $2000 \mathrm{~m}$

\section{MFHW 2}

Horizontal well of length $1000 \mathrm{~m}$ with

10 fractures with half-lengths $200 \mathrm{~m}$

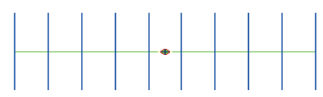

Square drainage area with sides of length $2000 \mathrm{~m}$
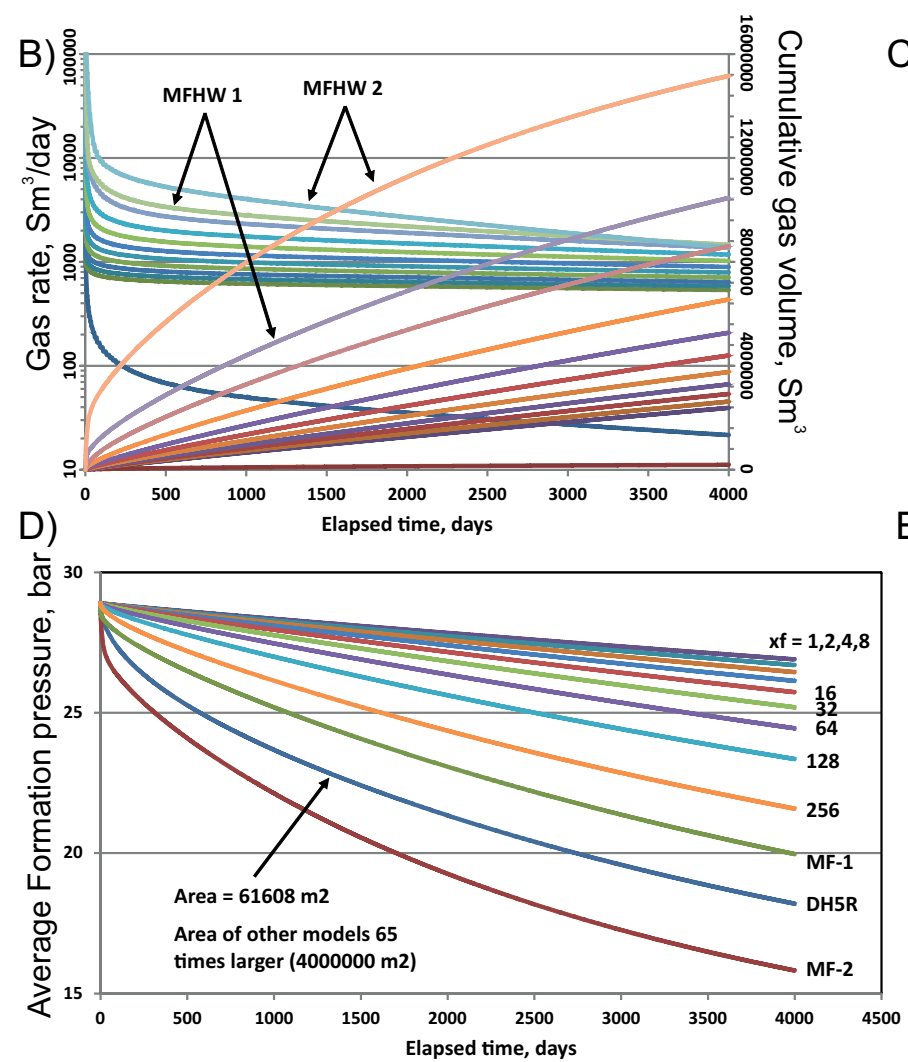

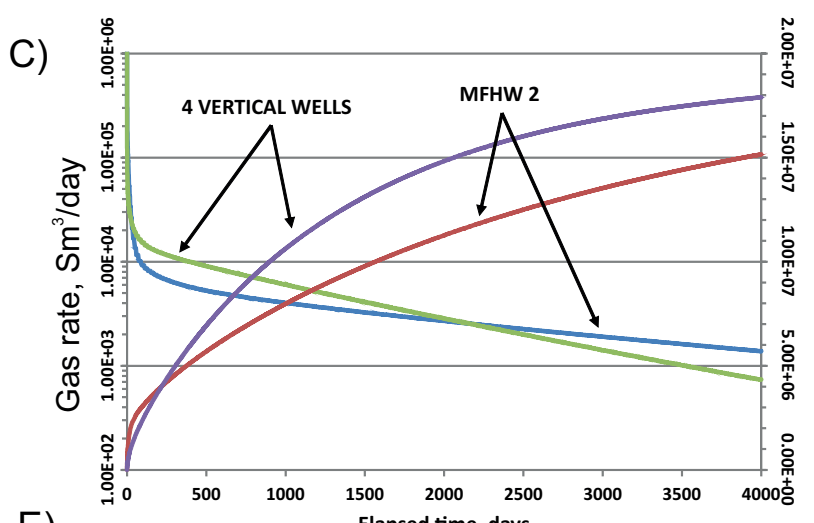

E)

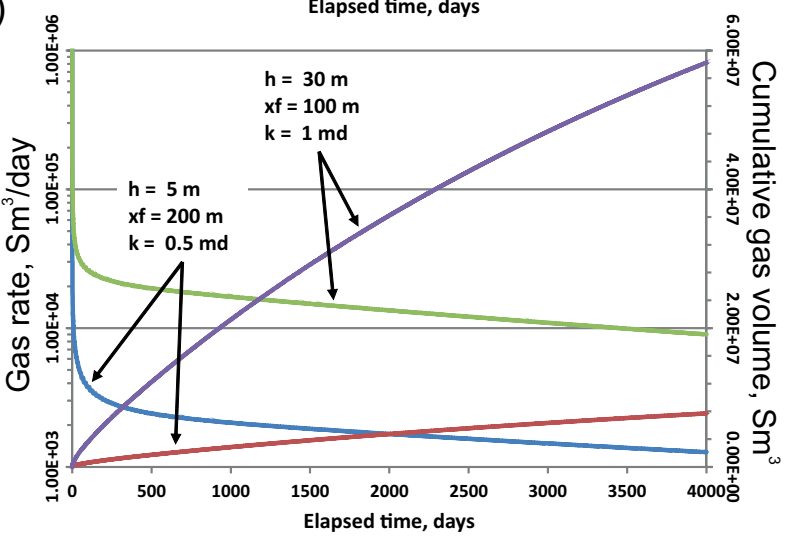

Figure 16. Predicted production forecasts using single-fracture vertical wells and multi-fractured horizontal wells. (A) Geometry of the multi-fractured horizontal wells production scenarios. (B) Production forecasts from multi-fractured horizontal wells (MFHW) and singlefracture vertical wells. (C) Production forecasts from a multi-fractured horizontal well (MFHW) scenario compared with production from 4 individual vertical wells. (D) Average formation pressures over time from the production scenarios illustrated in C. (E) Sensitivity of thickness, permeability and fracture half-length on the production performance.

strata. Some of these provide conventional structural closures such as the anticline within the Cretaceous Helvetiafjellet Formation targeted by the 7814/12-1 Kapp Laila well drilled in 1994. Contrary to conventional traps, the unconventional systems do not require discrete structures and thus represent an interesting petroleum exploration play. To fully quantify the resource potential of shale gas deposits onshore Svalbard, a dedicated effort focusing on quantifying key parameters (TOC, thickness, gas adsorption, etc.) is required. Strict environmental regulations would certainly hamper such an extensive regional study. The present work, however, indicates that a producible gas resource is located in Adventdalen in the immediate vicinity of Longyearbyen, and it is thus logical to consider whether this occurrence could provide a secure energy source in the future.

\section{Shale gas: a possible future cleaner energy source in Longyearbyen?}

In 2017 the United States became a net exporter of natural gas (Energy Information Administration, 2018b). This is a result of the boom in petroleum production from shales (unconventional exploration), which has continued since natural gas production became commercial from the Carboniferous Barnett Shale (Texas) around 2000 (Curtis, 2002). Shale oil production has also increased significantly as exemplified by the Cretaceous Eagle Ford shale play (Texas), which went from almost no production in 2010, to a production of roughly $1.4 \mathrm{Mbbl}$ per day in 2019 (Energy Information Administration, 2019). Unconventional natural gas production is based on the hydraulic fracturing method developed by the 
pioneering Mitchell Energy Corporation. Kuuskraa (2011) reports that shales with quartz-rich composition are more brittle than clay-rich shales, and therefore respond better to hydraulic fracturing and shale gas production. As previously described in this study, gas was retrieved both from a fractured, quartz-rich source rock interval of Upper Jurassic age (Agardhfjellet Formation) and from a Triassic low-permeability sandstone interval in Svalbard.

\section{Electricity from gas instead of coal; what is the advantage?}

According to the Intergovernmental Panel on Climate Change, the release of $\mathrm{CO}_{2}$ to the atmosphere is one of the main factors causing global warming. For this reason, there is a global effort to reduce $\mathrm{CO}_{2}$ emissions. Approximately $90 \%$ of the $\mathrm{CO}_{2}$ and $75 \%$ of the total greenhouse gas emissions in developed countries originates from the energy sector (Alavijeh et al., 2013). However, as the total greenhouse gas emission per kWh from coal-fired power plants is twice as large as that from natural gas-fired power plants (Agrawal et al., 2014; Tian et al., 2014) there is an incentive to exchange coal-fueled power plants with natural gas to reach global $\mathrm{CO}_{2}$ reduction goals (Tanaka et al., 2019). Besides $\mathrm{CO}_{2}$, other toxic air pollutants such as sulphur dioxide $\left(\mathrm{SO}_{2}\right)$, nitrogen oxides (NOx), particulate matter (soot, fly ash), carbon monoxide, volatile organic compounds and a range of heavy metals including arsenic $(\mathrm{As})$, lead $(\mathrm{Pb})$ and mercury $(\mathrm{Hg})$ are emitted by burning coal.

New technologies are being installed in coal plants to significantly reduce emissions. Xiong et al. (2016) expect, for example, $\mathrm{Hg}$ emission to be reduced with $50 \%$ by 2030. However, with an annual $12 \%$ increase in coal consumption due to the increasing energy demand in China, currently the world's largest contributor of $\mathrm{CO}_{2}$ to the atmosphere, the total yearly emission will still increase (Wang et al., 2012). Natural gas-fired power plants have much lower emissions of $\mathrm{CO}_{2}, \mathrm{NO}_{\mathrm{x}}$ and $\mathrm{SO}_{2}$ than coal plants (De Gouw et al., 2014). Roy \& Choi (2015) report up to 4 times lower emission for $\mathrm{NO}_{\mathrm{x}}$ and 50 times lower for $\mathrm{SO}_{2}$. Heavy metals are normally not associated with natural gases and such emissions from natural gas-fired power plants are therefore negligible.

The gas release from the organic-rich Upper Jurassic shales in well DH5R, which may be related to the leak-off test performed in the shale, resembles the unconventional exploration in the US. In this study, models have been produced to test whether this shale could produce enough natural gas to supply Svalbard locally with the yearly demand for electricity. Burning gas would, as mentioned, lead to a cleaner environment due to the reduction in the aforementioned air pollutants. The $\mathrm{CO}_{2}$ resulting from oxidation of the natural gas could also be directly re-injected into the subsurface from where the gas was produced to maintain pressure and minimise the $\mathrm{CO}_{2}$ footprint of the operation.

\section{Energy need and well count with gas replacing coal as energy source}

With just one well tested through a flow meter over a short period of time as a gas producer, there is considerable uncertainty about the potential for natural gas production as an energy source in Svalbard. Nevertheless, with the results above as guidelines, we can indicate what is required in terms of wells and productive formations to replace the energy currently provided from an estimated 25 thousand tons of coal per year with natural gas. Assuming that $0.8 \mathrm{Sm}^{3}$ of natural gas can replace the energy from $1 \mathrm{~kg}$ of coal, it will take close to 20 million Sm3 of natural gas per year to match the energy consumption on Svalbard (2015).

To give some rough guidelines of required well capacity, we consider first the case where the drainage area of the wells is only restricted by well spacing. The gas production could then be met with 5 vertical wells in a $20 \mathrm{~m}$-thick formation, and $2 \mathrm{~km}$ fracture spacing if the wells are stimulated with high-conductivity fractures with half-lengths of around $70 \mathrm{~m}$ or longer. A thicker interval requires fewer vertical wells to produce the gas, but these will have to fracture the formation at several intervals. With flow barriers restricting lateral flow, it would be necessary to drill more wells, or possibly use horizontal wells.

Although in-place volumes are most critical, flow properties are also important. Still, unless the permeability is extremely low, reduced permeability can be compensated by longer fractures or reduced well spacing to maintain production.

Extrapolation from the limited DH5R data is of course risky, especially without scenarios downplaying the possibility of very poor lateral continuity. However, the results do indicate that sufficient gas resources might be produced from the Agardhfjellet Formation to replace the energy presently (2015) needed in Svalbard. 


\section{Conclusions}

From this integrated study of the Agardhfjellet Formation it is concluded that:

- The gases from both wells have a thermogenic origin.

- The DH4 and DH5R gases are both dry with a methane content above $90 \%$. The DH5R gas is driest.

- The DH4 gas produced from a Triassic section is isotopically lighter than the DH5R gas produced from the Jurassic section (Agardhfjellet Formation).

- The gases are formed from source rocks at the end of the oil window.

- The DH4 gas originates from a thermally mature marine source rock, whereas the DH5R gas is derived from a thermally mature humic source rock.

- The DH4 gas is biodegraded

- The maceral composition of the Agardhfjellet Formation in well DH5R changes from vitrinite gasprone (type III kerogen) in the silty parts to liptiniterich oil prone (type II kerogen) in the clay-rich parts.

- Using properties derived from the DH5R test results it is possible to illustrate the potential of gas production from the Agardhfjellet Formation under various scenarios

- Since the production data from DH5R are consistent with gas flow from a narrow 'channel-like' drainage area of limited extent, this scenario has limited production potential.

- However, other models demonstrate how changes in different model parameters, such as size of drainage area, vertical versus horizontal wells, lengths of induced fractures, and thickness of the Agardhfjellet Formation, can significantly improve the production potential.

- The models show that gas from the Agardhfjellet Formation may supplement and in some cases totally replace coal for electricity and heat production in Longyearbyen, hence reducing the negative effects that burning coal has on the environment.

- Gas production also from the low-permeable Upper Triassic De Geerdalen Formation supports a potential for unconventional gas exploration in the area.
Acknowledgements. We thank the industry partners in the Longyearbyen $\mathrm{CO}_{2} \mathrm{Lab}$ for their enthusiasm, technical advice and financial contributions: ConocoPhillips, Equinor, Store Norske Spitsbergen Kulkompani, Statkraft, Lundin Norway, Baker Hughes and Leonhard Nilsen \& Sønner (http://co2-ccs.unis.no). We are also grateful for the financial support given by the CLIMIT-program administered by the Research Council of Norway and supported by Gassnova. This study was partly funded by the Research Centre for Arctic Petroleum Exploration (ARCEx, Norwegian Research Council grant number 228107), the FAJUTRI (Facies variations of Upper Jurassic source rock interval in the Barents Sea and Svalbard) project sponsored by ConocoPhillips and Lundin, and the JuLoCra project sponsored by AkerBP, Spirit energy, Lukoil, Wintershall-dea, Equinor and Lundin. Integrated Geochemical Interpretation is thanked for providing the pIGI software for geochemical interpretations, and Schlumberger is acknowledged for providing an academic licence for Petrel to UNIS. We sincerely appreciate the constructive comments by Tesfa Abay and an anonymous reviewer. This is a contribution of the NCCS (RCN\# 257579).

\section{References}

Abay, T., Karlsen, D., Lerch, B., Olaussen, S., Pedersen, J. \& Backer冈Owe, K. 2017: Migrated Petroleum in Outcropping Mesozoic Sedimentary Rocks in Spitsbergen: Organic Geochemical Characterization and Implications for Regional Exploration. Journal of Petroleum Geology 40, 5-36. https://doi.org/10.1111/jpg.12662.

Agrawal, K.K., Jain, S., Jain, A.K. \& Dahiya, S. 2014: Assessment of greenhouse gas emissions from coal and natural gas thermal power plants using life cycle approach. International Journal of Environmental Science and Technology 11, 1157-1164. https://doi.org/10.1007/s13762-013-0420-z.

Alavijeh, H.S., Kiyoumarsioskouei, A., Asheri, M., Naemi, S., Alavije, H.S. \& Tabrizi, H.B. 2013: Greenhouse gas emission measurement and economic analysis of Iran natural gas fired power plants. Energy policy 60, 200-207. https://doi.org/10.1016/j.enpol.2013.05.001.

Bergh, S.G., Braathen, A. \& Andresen, A. 1997: Interaction of basementinvolved and thin-skinned tectonism in the Tertiary fold-thrust belt of central Spitsbergen, Svalbard. American Association of Petroleum Geologists Bulletin 81, 637-661.

Bernard, B.B., Brooks, J.M. \& Sackett, W.M. 1976: Natural gas seepage in the Gulf of Mexico. Earth and Planetary Science Letters 31, 48-54. https://doi.org/10.1016/0012-821X(76)90095-9.

Berner, U. \& Faber, E.J.O.G. 1996: Empirical carbon isotope/maturity relationships for gases from algal kerogens and terrigenous organic matter, based on dry, open-system pyrolysis. Organic Geochemistry 24, 947-955. https://doi.org/10.1016/S0146-6380(96)00090-3.

Betlem, P., Senger, K. \& Hodson, A. 2019: 3D thermo-baric modelling of the gas hydrate stability zone onshore central Spitsbergen, Arctic Norway. Marine and Petroleum Geology 100, 246-262. https://doi.org/10.1016/j.marpetgeo.2018.10.050.

Birchall, T., Senger, K. \& Olaussen, S. 2018: Subnormal Pressure Regimes Of The Northern Barents Shelf: Causes And Implications For Hydrocarbon Exploration. EAGE Annual Conference \& Exhibition, 10-14th June 2018, Copenhagen, Denmark, p. 1-5. https://doi.org/10.3997/2214-4609.201800913.

Braathen, A., Bergh, S.G. \& Maher, H.D.Jr. 1999: Application of a critical wedge taper model to the Tertiary transpressional foldthrust belt on Spitsbergen, Svalbard. Geological Society of America Bulletin 111, 1468-1485.

https://doi.org/10.1130/0016-7606(1999)111<1468:AOACWT>2.3.CO;2.

Braathen, A., Bælum, K., Christiansen, H.H., Dahl, T., Eiken, O., Elvebakk, H., Hansen, F., Hanssen, T.H., Jochmann, M., Johansen, T.A., Johnsen, H., Larsen, L., Lie, T., Mertes, J., Mørk, A., Mørk, M.B., Nemec, W.J., Olaussen, S., Oye, V., Rød, K., Titlestad, G.O., Tveranger, J. \& Vagle, K. 2012: Longyearbyen $\mathrm{CO}_{2}$ lab of Svalbard, Norway - first assessment of the sedimentary succession for $\mathrm{CO}_{2}$ storage. Norwegian Journal of Geology 92, 353-376. 
Brekke, T., Krajewski, K.P. \& Hubred, J.H. 2014: Organic geochemistry and petrography of thermally altered sections of the Middle Triassic Botneheia Formation on south-western Edgeøya, Svalbard. Norwegian Petroleum Directorate Bulletin 11, 111-128.

Cardott, B.J. 2012: Thermal maturity of Woodford Shale gas and oil plays, Oklahoma, USA. International Journal of Coal Geology 103, 109-119. https://doi.org/10.1016/j.coal.2012.06.004.

Cavanagh, A.J., Di Primio, R., Scheck-Wenderoth, M. \& Horsfield, B. 2006: Severity and timing of Cenozoic exhumation in the southwestern Barents Sea. Journal of the Geological Society 163, 761-774. https://doi.org/10.1144/0016-76492005-146.

Curtis, J.B. 2002: Fractured shale-gas systems. American Association of Petroleum Geologists bulletin 86, 1921-1938. https://doi.org/10.1306/61EEDDBE-173E-11D7-8645000102C1865D.

Dallmann, W.K., Major, H., Haremo, P. \& Andersen, A. 2001: Geological map of Svalbard, scale 1:100,000, Sheet C9G Adventdalen. In Polarinstitutt, N. (Ed.): Temakart No. 31/32, Tromsø.

De Gouw, J.A., Parrish, D.D., Frost, G.J. \& Trainer, M. 2014: Reduced emissions of $\mathrm{CO}_{2}, \mathrm{NO}_{\mathrm{x}}$, and $\mathrm{SO}_{2}$ from US power plants owing to switch from coal to natural gas with combined cycle technology. Earth's Future 2, 75-82. https://doi.org/10.1002/2013EF000196.

Dimakis, P., Braathen, B.I., Faleide, J.I., Elverhøi, A. \& Gudlaugsson, S.T. 1998: Cenozoic erosion and the preglacial uplift of the Svalbard-Barents Sea region. Tectonophysics 300, 311-327. https://doi.org/10.1016/S0040-1951(98)00245-5.

Dypvik, H. 1984: Jurassic and Cretaceous black shales of the Janusfjellet formation, Svalbard, Norway. Sedimentary Geology 41, 235-248. https://doi.org/10.1016/0037-0738(84)90064-2.

Dörr, N., Lisker, F., Jochmann, M., Rainer, T., Schlegel, A., Schubert, K. \& Spiegel, C. 2019: Subsidence, rapid inversion, and slow erosion of the Central Tertiary Basin of Svalbard: Evidence from the thermal evolution and basin modeling. In Piepjohn, K., Strauss, J.V., Reinhardt, L. \& McClelland, W.C. (Eds.): Circum-Arctic Structural Events: Tectonic Evolution of the Arctic Margins and Trans-Arctic Links with Adjacent Orogens, Geological Society of America 541, pp. 169-189. https://doi.org/10.1130/2018.2541(09).

Elvebakk, H. 2010: Results of borehole logging in well LYB CO2, Dh4 of 2009, Longyearbyen, Svalbard. NGU Report 2010.018, 35 pp.

Energy Information Administration. 2018a. Energy Information Administration Natural gas explained. Where our natural gas comes from.

https://www.eia.gov/energyexplained/natural-gas/where-our-naturalgas-comes-from.php (11.11.2019)

Energy Information Administration. 2018b. Energy Information Administration Natural Gas Annual 2017.

https://www.eia.gov/naturalgas/annual/archive/2017/ (11.11.2019)

Energy Information Administration. 2019. Energy Information Administration. Petroleum drilling.

https://www.eia.gov/petroleum/drilling/pdf/eagleford.pdf. (11.11.2019)

Faber, E. \& Stahl, W. 1984: Geochemical surface exploration for hydrocarbons in the North Sea: American Association of Petroleum Geologists Bulletin 68, 363-386. https://doi.org/10.1306/AD460A26-16F7-11D7-8645000102C1865D.

Faleide, J.I., Bjørlykke, K. \& Gabrielsen, R.H. 2015: Geology of the Norwegian continental shelf. Petroleum Geoscience, Springer, 603637. https://doi.org/10.1007/978-3-642-34132-8_25.

Glørstad-Clark, E., Faleide, J.I., Lundschien, B.A. \& Nystuen, J.P. 2010: Triassic seismic sequence stratigraphy and paleogeography of the western Barents Sea area. Marine and Petroleum Geology 27, 14481475. https://doi.org/10.1016/j.marpetgeo.2010.02.008.

Grantz, A., Hart, P.E. \& Childers, V.A. 2011: Chapter 50 Geology and tectonic development of the Amerasia and Canada Basins, Arctic Ocean. In Spencer, A.M., Embry, A.F., Gautier, D.L., Stoupakova, A.V. \& Sørensen, K. (eds.): Arctic Petroleum Geology, Geological Society of London, Memoir 35, pp. 771-799. https://doi.org/10.1144/M35.50.
Grogan, P., Østvedt-Ghazi, A.M., Larssen, G.B., Fotland, B., Nyberg, K., Dahlgren, S. \& Eidvin, T. 1999: Structural elements and petroleum geology of the Norwegian sector of the northern Barents Sea. Geological Society of London, Petroleum Geology Conference series 5, 247-259. https://doi.org/10.1144/0050247.

Grundvåg, S.A., Marin, D., Kairanov, B., Śliwińska, K., Nøhr-Hansen, H., Escalona, A. \& Olaussen, S. 2017: The Lower Cretaceous succession of the northwestern Barents Shelf: Onshore and offshore correlations. Marine and Petroleum Geology 86, 834-857. https://doi.org/10.1016/j.marpetgeo.2017.06.036.

Grundvåg, S.-A., Engholm Jelby, M., Śliwińska, K.K., Nøhr-Hansen, H., Aadland, T., Elvelund Sandvik, S.E., Tennvassås, I., Engen, T. \& Olaussen, S. 2019: Sedimentology and palynology of the Lower Cretaceous succession of central Spitsbergen: integration of subsurface and outcrop data. Norwegian Journal of Geology 99, 247-278. https://doi.org/10.17850/njg006.

Helland-Hansen, W. 2010: Facies and stacking patterns of shelfdeltas within the Palaeogene Battfellet Formation, Nordenskiöld Land, Svalbard: implications for subsurface reservoir prediction. Sedimentology 57, 190-208. https://doi.org/10.1111/j.1365-3091.2009.01102.x.

Hodson, A.J., Nowak, A., Senger, K., Christiansen, H.H., Jessen, S., Hornum, M., Betlem, P., Thornton, S., Turchyn, A., Olaussen, S. \& Marca, A. In review: Direct escape of sub-permafrost methane through open system pingos and its contribution to atmospheric emissions. Nature communications.

Huq, F., Smalley, P.C., Mørkved, P.T., Johansen, I., Yarushina, V. \& Johansen, H. 2017: The Longyearbyen CO2 Lab: Fluid communication in reservoir and caprock. International Journal of Greenhouse Gas Control 63, 59-76. https://doi.org/10.1016/j.ijggc.2017.05.005.

Katz, B.J., Narimanov, A. \& Huseinzadeh, R. 2002: Significance of microbial processes in gases of the South Caspian basin. Marine and Petroleum Geology 19, 783-796. https://doi.org/10.1016/S0264-8172(02)00086-7.

Klausen, T.G., Müller, R., Slama, J. \& Helland-Hansen, W. 2017: Evidence for Late Triassic provenance areas and Early Jurassic sediment supply turnover in the Barents Sea Basin of northern Pangea. Lithosphere 9, 14-28. https://doi.org/10.1130/L556.1.

Klausen, T.G., Müller, R., Sláma, J., Olaussen, S., Rismyhr, B. \& Helland-Hansen, W. 2018: Depositional history of a condensed shallow marine reservoir succession: stratigraphy and detrital zircon geochronology of the Jurassic Stø Formation, Barents Sea. Journal of the Geological Society 175, 130-145. https://doi.org/10.1144/jgs2017-024.

Koevoets, M.J., Abay, T.B., Hammer, Ø. \& Olaussen, S. 2016: Highresolution organic carbon-isotope stratigraphy of the Middle Jurassic-Lower Cretaceous Agardhfjellet Formation of central Spitsbergen, Svalbard. Palaeogeography, Palaeoclimatology, Palaeoecology 449, 266-274. https://doi.org/10.1016/j.palaeo.2016.02.029.

Koevoets, M.J., Hammer, Ø., Olaussen, S., Senger, K. \& Smelror, M. 2019: Integrating subsurface and outcrop data of the Middle Jurassic to Lower Cretaceous Agardhfjellet Formation in central Spitsbergen. Norwegian Journal of Geology 99, 213-246. https://dx.doi.org/10.17850/njg98-4-01.

Krajewski, K.P. 2008: The Botneheia Formation (Middle Triassic) in Edgeøya and Barentsøya, Svalbard: lithostratigraphy, facies, phosphogenesis, paleoenvironment. Polish Polar Research 29, 319364.

Krajewski, K., Karcz, P., Wozny, E. \& Mørk, A. 2007: Type section of the Bravaisberget Formation (Middle Triassic) at Bravaisberget, western Nathorst Land, Spitsbergen, Svalbard. Polish Polar Research $28,79-122$.

Kuuskraa, V.2011: Worldwide assessment underscores vast potential of gas shale resources. American Oil \& Gas Reporter 54, 40-46. 
Larsen, L. 2012: Analyses of Sept. 2011 Upper Zone Injection and Falloff Data from DH6 and Interference Data from DH5. Longyearbyen $\mathrm{CO}_{2}$ Lab UNIS Report 2012.

Larsen, L. 2013a: Analyses of DH4 Lower Zone Injection and Falloff Data, August 12, 2010 - July 25. Longyearbyen $\mathrm{CO}_{2}$ lab internal report, $44 \mathrm{pp}$

Larsen, L. 2013b: Analyses of DH4 Upper Zone Injection and Falloff Data, September 5 - October 15, 2013. Longyearbyen $\mathrm{CO}_{2}$ lab internal report, $44 \mathrm{pp}$.

Leever, K.A., Gabrielsen, R.H., Faleide, J.I. \& Braathen, A. 2011: A transpressional origin for the West Spitsbergen fold-and-thrust belt: Insight from analog modeling. Tectonics 30, 1-24. https://doi.org/10.1029/2010TC002753.

Leythaeuser, D., Schaefer, R., Cornford, C.T. \& Weiner, B. 1979: Generation and migration of light hydrocarbons (C2- C7) in sedimentary basins. Organic geochemistry 1, 191-204. https://doi.org/10.1016/0146-6380(79)90022-6.

Liira, M., Noormets, R., Sepp, H., Kekišev, O., Maddison, M. \& Olaussen, S. 2019: Sediment geochemical study of hydrocarbon seeps in Isfjorden and Mohnbukta: a comparison between western and eastern Spitsbergen, Svalbard. Arktos, 1-14. https://doi.org/10.1007/s41063-019-00067-7.

Maher, H.D.Jr. 2001: Manifestations of the Cretaceous High Arctic Large Igneous Province in Svalbard. The Journal of Geology 109, 91-104. https://doi.org/10.1086/317960.

Marín, D., Escalona, A., Śliwińska, K.K., Nøhr-Hansen, H. \& Mordasova, A. 2016: Sequence stratigraphy and lateral variability of Lower Cretaceous clinoforms in the southwestern Barents Sea. American Association of Petroleum Geologists Bulletin 101, 14871517. https://doi.org/10.1306/10241616010.

Marshall, C., Uguna, J., Large, D.J., Meredith, W., Jochmann, M., Friis, B., Vane, C., Spiro, B.F., Snape, C.E. \& Orheim, A. 2015: Geochemistry and petrology of palaeocene coals from Spitzbergen - Part 2: Maturity variations and implications for local and regional burial models. International Journal of Coal Geology 143, 1-10. https://doi.org/10.1016/j.coal.2015.03.013.

Midtkandal, I. \& Nystuen, J.P. 2009: Depositional architecture of a lowgradient ramp shelf in an epicontinental sea: the lower Cretaceous of Svalbard. Basin Research 21, 655-675.

https://doi.org/10.1111/j.1365-2117.2009.00399.x.

Mulrooney, M.J., Larsen, L., Rismyhr, B., Van Stappen, J., Senger, K., Braathen, A., Mørk, M.B., Olaussen, S., Cnudde, V. \& Ogata K. 2019: Fluid flow properties of a potential unconventional $\mathrm{CO}_{2}$ storage unit in central Spitsbergen: the Upper Triassic to Middle Jurassic Wilhelmøya Subgroup. Norwegian Journal of Geology 99, 279-310. https://doi.org/10.17850/njg002.

Mørk, A., Knarud, R. \& Worsley, D. 1982: Depositional and diagenetic environments of the Triassic and Lower Jurassic succession of Svalbard. In Embry, A.F. \& Balkwill, H.R. (eds.): Arctic Geology and Geophysics, Canadian Society of Petroleum Geologists, pp. 371-398.

Mørk, A., Elvebakk, G., Forsberg, A.W., Hounslow, M.W., Nakrem, H.A., Os-Vigran, J. \& Weitschat, W. 1999: The type section of the Vikinghøgda Formation: a new Lower Triassic unit in central and eastern Svalbard. Polar Research 18, 51-82. https://doi.org/10.3402/polar.v18i1.6558.

Mørk, M.B.E. 2013: Diagenesis and quartz cement distribution of lowpermeability Upper Triassic-Middle Jurassic reservoir sandstones, Longyearbyen $\mathrm{CO}_{2}$ lab well site in Svalbard, Norway. American Association of Petroleum Geologists Bulletin 97, 577-596. https://doi.org/10.1306/10031211193.

Nagy, J., Reolid, M. \& Rodriguez-Tovar, F.J. 2009: Foraminiferal morphogroups in dysoxic shelf deposits from the Jurassic of Spitsbergen. Polar Research 28, 214-221.

https://doi.org/10.1111/j.1751-8369.2009.00112.x.

NPN 1977: Final drilling report, Tromsøbreen 1, 90 pp.
Nøttvedt, A., Cecchi, M., Gjelberg, J.G., Kristensen, S.E., Lønøy, A., Rasmussen, A., Rasmussen, E., Skott, P.H. \& Veen, P.M.v. 1993a: Svalbard-Barents Sea correlation: a short review. In Vorren, T.O., Bergsager, E., Dahl-Stamnes, Ø.A., Holter, E., Johansen, B., Lie, E. \& Lund, T.B. (eds.): Arctic Geology and Petroleum Potential, Amsterdam, Elsevier, pp. 363-375. https://doi.org/10.1016/B978-0-444-88943-0.50027-7.

Nøttvedt, A., Livbjerg, F., Midbøe, P. S. \& Rasmussen, E. 1993b: Hydrocarbon potential of the Central Spitsbergen Basin. In Vorren, T.O., Bergsager, E., Dahl-Stamnes, Ø.A., Holter, E., Johansen, B., Lie, E. \& Lund, T.B. (eds.): Arctic Geology and Petroleum Potential, Amsterdam, Elsevier, pp. 333-361.

https://doi.org/10.1016/B978-0-444-88943-0.50026-5.

Ogata, K., Senger, K., Braathen, A., Tveranger, J. \& Olaussen, S. 2014: Fracture systems and meso-scale structural patterns in the siliciclastic Mesozoic reservoir-caprock succession of the Longyearbyen $\mathrm{CO}_{2}$ Lab project: implications for geologic $\mathrm{CO}_{2}$ sequestration on Central Spitsbergen, Svalbard. Norwegian Journal of Geology 94, 121-154.

Ohm, S.E., Karlsen, D.A. \& Austin, T.J.F. 2008: Geochemically driven exploration models in uplifted areas: Examples from the Norwegian Barents Sea. American Association of Petroleum Geologists Bulletin 92, 1191-1223. https://doi.org/10.1306/06180808028.

Piepjohn, K., von Gosen, W. \& Tessensohn, F. 2016: The Eurekan deformation in the Arctic: an outline. Journal of the Geological Society 173, 1007-1024. https://doi.org/10.1144/jgs2016-081.

Polteau, S., Hendriks, B.W., Planke, S., Ganerød, M., Corfu, F., Faleide, J.I., Midtkandal, I., Svensen, H.S. \& Myklebust, R. 2016: The Early Cretaceous Barents Sea Sill Complex: Distribution, ${ }^{40} \mathrm{Ar} /{ }^{39} \mathrm{Ar}$ geochronology, and implications for carbon gas formation. Palaeogeography, Palaeoclimatology, Palaeoecology 441, 83-95. https://doi.org/10.1016/j.palaeo.2015.07.007.

Rismyhr, B., Bjærke, T., Olaussen, S., Mulrooney, M.J. \& Senger K. 2019: Facies, palynostratigraphy and sequence stratigraphy of the Wilhelmøya Subgroup (Upper Triassic-Middle Jurassic) in western central Spitsbergen, Svalbard. Norwegian Journal of Geology 99, 183-212. https://doi.org/10.17850/njg001.

Roy, A. \& Choi, Y. 2015: New Directions: Potential impact of changing the coal-natural gas split in power plants: An emissions inventory perspective for criteria pollutants. Atmospheric Environment 102, 413-415. https://doi.org/10.1016/j.atmosenv.2014.10.063.

Ryseth, A. 2014: Sedimentation at the Jurassic-Triassic boundary, south囚west Barents Sea. From Depositional Systems to Sedimentary Successions on the Norwegian Continental Margin, 187-214. https://doi.org/10.1002/9781118920435.ch9.

Senger, K., Mulrooney, M., Braathen, A., Ogata, K. \& Olaussen, S. 2016: Integrated Characterization of an Organic-rich Caprock Shale, Svalbard, Arctic Norway. Fifth European Association of Geoscientists \& Engineers Shale Workshop, Catania, Italy, 2-4 May. https://doi.org/10.3997/2214-4609.201600430.

Senger, K., Tveranger, J., Ogata, K., Braathen, A. \& Planke, S. 2014: Late Mesozoic magmatism in Svalbard: A review. Earth-Science Reviews 139, 123-144. https://doi.org/10.1016/j.earscirev.2014.09.002.

Senger, K., Brugmans, P., Grundvåg, S.A., Jochmann, M., Nøttvedt, A., Olaussen, S., Skotte, A., \& Smyrak-Sikora, A. 2019: Petroleum, coal and research drilling onshore Svalbard: a historical perspective. Norwegian Journal of Geology 99, 353-424. https://doi.org/10.17850/njg99-3-1.

Senger, K., Roy, S., Braathen, A., Buckley, S.J., Bælum, K., Gernigon, L., Mjelde, R., Noormets, R., Ogata, K., Olaussen, S., Planke, S., Ruud, B.O. \& Tveranger, J. 2013: Geometries of doleritic intrusions in central Spitsbergen, Svalbard: an integrated study of an onshore-offshore magmatic province with implications on $\mathrm{CO}_{2}$ sequestration. Norwegian Journal of Geology 93, 143-166.

Smelror, M. \& Larssen, G.B. 2016: Are there Upper Cretaceous sedimentary rocks preserved on Sørkapp Land, Svalbard? Norwegian Journal of Geology 96, 1-12. https://doi.org/10.17850/njg96-2-05. 
Steel, R.J. \& Worsley, D. 1984: Svalbard's post-Caledonian strata - an atlas of sedimentational patterns and paleogeographic evolution. In Spencer, A.M. (ed.): Petroleum Geology of the North European Margin, London, Graham \& Trotman, pp. 109-135.

https://doi.org/10.1007/978-94-009-5626-1_9.

Steel, R.J., Gjelberg, J., Helland-Hansen, W., Kleinspehn, K., Nøttvedt, A. \& Rye-Larsen, M. 1985: The Tertiary strike-slip basins and orogenic belt of Spitsbergen. In Biddle, K.T. \& Christie-Blick, N. (eds.): Strike-slip deformation, basin formation, and sedimentation, Society of Economic Paleontologists and Mineralogists Special Publication 37, pp. 339-359. https://doi.org/10.2110/pec.85.37.0339.

Tanaka, K., Cavalett, O., Collins, W.J. \& Cherubini, F. 2019: Asserting the climate benefits of the coal-to-gas shift across temporal and spatial scales. Nature Climate Change 9, 389-396. https://doi.org/10.1038/s41558-019-0457-1.

Tennbakk, B., Fiksen, K., Borsche, T., Grøndahl, R., Jarstein, S. \& Ramm, B. 2018: Alternativer for framtidig energiforsyning på Svalbard. THEMA Rapport 2018-09, 136 pp.

Tian, H., Liu, K., Zhou, J., Lu, L., Hao, J., Qiu, P., Gao, J., Zhu, C., Wang, K. \& Hua, S. 2014: Atmospheric Emission Inventory of Hazardous Trace Elements from China's Coal-Fired Power Plants Temporal Trends and Spatial Variation Characteristics. Environmental Science \& Technology 48, 3575-3582. https://doi.org/10.1021/es404730j.

Wang, S., Zhang, L., Zhao, B., Meng, Y. \& Hao, J. 2012: Mitigation Potential of Mercury Emissions from Coal-Fired Power Plants in China. Energy \& Fuels 26, 4635-4642. https://doi.org/10.1021/ef201990x.

Wang, W.C., Zhang, L.Y., Liu, W.H., Kang, Y. \& Ren, J.H. 2005: Effects of biodegradation on the carbon isotopic composition of natural gas-A case study in the bamianhe oil field of the Jiyang Depression, Eastern China. Geochemical Journal 39, 301-309. https://doi.org/10.2343/geochemj.39.301.

Whiticar, M.J. 1994: Correlation of natural gases with their sources. Memoirs-American Association of Petroleum Geologists, 261-261.

Worsley, D. 2008: The post-Caledonian development of Svalbard and the western Barents Sea. Polar Research 27, 298-317. https://doi.org/10.1111/j.1751-8369.2008.00085.x.

Xiong, T., Jiang, W. \& Gao, W. 2016: Current status and prediction of major atmospheric emissions from coal-fired power plants in Shandong Province, China. Atmospheric Environment 124, 46-52. https://doi.org/10.1016/j.atmosenv.2015.11.002. 